\title{
Performance and degradation assessment of large-scale grid-connected solar photovoltaic power plant in tropical semi-arid environment of India
}

\author{
Maria Malvoni $^{\mathrm{a}, *}$, Nallapaneni Manoj Kumar ${ }^{\mathrm{b}}$, Shauhrat S Chopra ${ }^{\mathrm{b}, *}$, Nikos Hatziargyriou ${ }^{\mathrm{a}}$ \\ ${ }^{a}$ School of Electrical and Computer Engineering, National Technical University of Athens, Greece \\ ${ }^{\mathrm{b}}$ School of Energy and Environment, City University of Hong Kong, Kowloon, Hong Kong
}

\section{A R T I C L E I N F O}

\section{Keywords:}

Photovoltaic performance

Photovoltaic degradation

Statistical methods

Utility-scale PV system

Semi-arid climates

\begin{abstract}
A B S T R A C T
The performance and degradation of a $1 \mathrm{MWp}$ utility-scale photovoltaic (PV) system located in the tropical semiarid climate of India is investigated based on four years of monitored data. The reference yield, final yield, system efficiency, capacity factor, and performance ratio are $4.64 \mathrm{~h} /$ day $6.23 \mathrm{~h} /$ day, 11\%, 19.33\%, and 74.73\%, respectively, according to the standard IEC 61724. The performance is compared to other large-scale PV systems in different climate conditions. The degradation of the PV plant is quantified by using various statistical methods. These methods include the linear least-squares regression (LLS), the classical seasonal decomposition (CSD), the Holt-Winters seasonal model (HW), and the seasonal and trend decomposition using loess (STL). The degradation rate is estimated at $0.27 \%$ /year, $0.32 \%$ /year, $0.50 \%$ /year, and $0.27 \%$ /year, respectively, after 50 months operating period. The degradation accuracy analysis classifies the LLS and HW as lower accuracy methods $(0.22 \%)$ than CSD $(0.11 \%)$ and STL $(0.15 \%)$. A comparison of the degradation of mono-Si PV systems for various locations is performed using different statistical methods. This study contributes to the improvements in the knowledge of PV degradation in the Indian climate.
\end{abstract}

\section{Introduction}

Utility-scale solar projects maintained the largest share of photovoltaics (PV) installations in India while the rooftop PV contribute a minor share. Recent statistics reveal that the share of installed utilityscale PV power plants in India contributes about $88 \%$ followed by China (82\%), USA (54\%), Spain (40\%), Germany (27\%), and Australia (3\%) (Bridge To India, 2017). At present, about 90\% of PV modules the are currently installed are crystalline based (Choi et al., 2018; JägerWaldau, 2018; Masuko et al., 2014; Silvestre et al., 2018). Studies suggest that the same trends in the installation of crystalline modules will continue due to the abundant availability of silicon material and the advantages associated with it when compared to other PV modules.

Crystalline silicon PV modules are gaining much acceptance in India, and their share is expected to grow in the coming years (Bridge To India, 2017). Efficiency and longer life span are the reasons for their adoption in the Indian PV market. These PV modules are designed by series and parallel combinations of crystalline solar cells that are meant to operate effectively under the standard test conditions (STC). The manufacturer typically gives the nameplate rating based on STC $\left(1000 \mathrm{~W} / \mathrm{m}^{2}\right.$ solar irradiance, $25^{\circ} \mathrm{C}$ cell temperature, $1 \mathrm{~m} / \mathrm{s}$ wind speed, and 1.5 air mass) for all the PV modules they manufacture. PV modules, however, have demonstrated variations in the performance concerning real-life weather conditions. In its lifetime, solar PV modules experience performance decline once they exposed to outdoor field conditions. During the PV module operation in real-life weather conditions, they experience many operational and environmental stresses, and these have a negative impact on the overall energy outputs (Quansah and Adaramola, 2019). Few of the stress conditions for a PV module include variation in solar irradiance, change in the angle of incidence, high/low module temperature, relative humidity, soiling, and wind speed (Dubey et al., 2013a,b; Kurnik et al., 2011; Rajput et al., 2017; Ogbomo et al., 2018). Knowing the operational performance is imperative for realistic financial modeling of utility-scale or large-scale solar PV systems. Besides, adequate knowledge on PV degradation rates concerning real-life weather conditions serve as meaningful input information for future developments in PV technology (Munoz et al., 2011). The interest in these operational and degradation assessments focus on the performance of PV systems on a long-term basis or throughout their useful lifetime, which is about $20-25$ years.

In the present study, operational performance assessment and degradation analysis of field exposed utility-scale crystalline silicon PV system for four years is carried out. The installed capacity of the system is $1 \mathrm{MWp}$, and it is exposed to semi-arid climates in Telangana State of

\footnotetext{
* Corresponding authors.

E-mail addresses: maria.malvoni@gmail.com (M. Malvoni), sschopra@cityu.edu.hk (S.S. Chopra).
} 
Southern India. The main objective of this research study is to understand the long-term performance and the impacts of degradation. A detailed performance analysis is done based on the monitored data from the power plant by following the IEA PVPS standards that define key performance indicators allowing to assess the overall energy performance of any PV plant. An uncertainty assessment for the PV energy yield is performed to account for the uncertain elements in the PV.

For the degradation analysis, four statistical methods are considered. These methods include linear least-squares regression (LLS), the classical seasonal decomposition (CSD), the Holt-Winters seasonal model (HW), and the seasonal and trend decomposition using loess (STL). The performance and degradation results obtained are compared with the already existed studies in the literature. The present assessment can support investors in the Indian PV sector. Furthermore, the PV industry could benefit from a long-term performance assessment based on real operating conditions of a large PV power installation.

The paper is articulated as follows: an overview of PV system performance and degradation studies are presented in Section 2; utilityscale solar PV system considered for this study is described in Section 3; the methodology used for PV system performance assessment and four statistical methods for degradation analysis is clearly explained in Sections 4 and 5 respectively; performance and degradation results are discussed and compared with other works from the literature are given in Section 6 and conclusions for the effective operation of the PV systems are drawn and presented in Section 7.

\section{Literature review}

This section performs a literature review on PV system operational performance and degradation. Many studies have reported the consolidated degradation rates of PV systems based on performance ratios. Along with the individual researchers, few organizations, namely the National Renewable Energy Laboratories (NREL), SunPower, EURAC Research, Fraunhofer ISE, and the University of Cyprus, contributed to the degradation studies of PV. The NREL scientists (Jordan and Kurtz, 2013), presented a consolidated value on the degradation rates by reviewing the published content in the last 40 years (approximately 2000 degradation rates) and given a median annual performance degradation rate of $0.5 \%$. SunPower is a PV module manufacturing company, reported that the PV module degrades at $1.25 \pm 0.25 \%$. This consolidated value is based on an extensive study related to PV degradation as per the data collected from 179 PV systems (SunPower, 2013). EURAC Research also conducted a comprehensive study and reported the degradation rates for PV modules (c-Si: 0.75\%/year; a-Si: 3\%/year, CdTe: $2 \%$ /year; CIGS and Micromorph: $2-3 \%$ /year) (Belluardo et al., 2013). Fraunhofer ISE also reported that PV module degradation would range between 0.5 and $0.6 \%$ /year (Kiefer et al., 2018). On the other side, the research teams at the University of Cyprus came up with various methods to estimate the degradation based on long term monitored data (PV, 2020). Individual researchers, for example, Ndiaye et al. (2013) studied the degradation of silicon photovoltaic modules by conducting an extensive review and concluded that silicon-based PV modules exhibit degradation that could be much worse on a long term basis. Sharma and Chandel (2013a) studied the significance of investigating the degradation analysis based on the performance ratio of PV systems to understand the long-term reliability under outdoor operations. In their study, methods for performance evaluation and degradation analysis were clearly described. A report on PV module degradation and reliability for specific to Indian climatic conditions is presented based on an All India Survey conducted by three organization consortia comprising of, the National Centre for Photovoltaic Research and Education (NCPRE), Indian Institute of Technology, Bombay (IITB), and National Institute of Solar Energy (NISE) under Ministry of New and Renewable Energy (MNRE), Govt. of India. The All India survey reports reveal that crystalline PV modules exposed to outdoor conditions in Indian weather conditions experience performance degradation within the range of -0.6 to $-5 \%$ /year, excluding the light-induced degradation for crystalline silicon modules. It is also suggested that, the degradation is PV technology specific and would depend on many operational and environmental stresses (Dubey et al., 2013a,b; Dubey et al., 2014; Chattopadhyay, 2016; Golive et al., 2018).

In recent years, researchers are increasingly studying on the various reasons for degradation with a vision to understand the risks and to enhance the long-term reliability. The degradation process also impacts on the PV life cycle environmental-economic assessment (Rajput et al., 2020). In a recent study, Choi et al. (2018) investigated the performance and degradation of silicon PV modules exposed to outdoor conditions in Japan and demonstrated the reasons for degradation. A study by Chandel et al. (2015) showed evidence of crystalline siliconbased PV array degradation, which was exposed to harsh weather conditions in the western Himalayan region of India for 28 years. He pointed out reasons for degradation, as encapsulant discoloration, delamination, oxidation of front grid fingers, and glass breakages. A study by Munoz et al. (2011) presented the scenarios of early degradation possibility in silicon-based PV modules caused by yellowing, delamination, bubbles, cracks in the cells, defects in the anti-reflective coating, burnt cells due to hotspot problems. Han et al. (2018) Presented a study on the degradation analysis of crystalline silicon photovoltaic modules exposed over 30 years in the hot-humid climate in China. The observed reasons for degradation are cracks of the back-sheet, corrosion, water vapor transmission rate on the module.

On the other hand, Rajput et al. (2019) explored the failure mechanism of PV modules that lead to performance degradation in real outdoor conditions. It is suggested that identifying the severity of the PV failure mechanism using a risk priority number (RPN) analysis would give enough information on the degradation. Kumar et al. (2019b) presented the realistic economic modeling of the PV system showing the long-term impact of degradation on the revenue losses.

Several researchers have studied the phenomenon of the influence on weather conditions on PV performance degradation. For example, Malvoni et al. (2016) analyzed the performance of the $960 \mathrm{kWp} \mathrm{PV}$ system highlighting the influence of the Mediterranean climate on the PV system losses. Bouraiou et al. (2015) studied the performance of PV modules and corresponding impacts on it with the influence of weather parameters, especially the high temperatures under the climatic conditions of the Saharan environment in the south of Algeria. Makrides et al. (2014) investigated the performance loss rate (PLR) of 12 PV technologies exposed to outdoor conditions using statistical modeling and concluded that the PLR values varied up to $0.65 \%$ year. Also, it concluded that PLR or degradation would be varied significantly with technology and the duration of outdoor operational exposure. Kichou et al. (2016a,b) investigated the degradation modes and degradation rates of thin-film PV modules exposed to the relatively dry and sunny climate in Spain. Kichou et al. (2018) analyzed the behaviour of cadmium telluride (CdTe) and crystalline silicon (c-Si) PV modules deployed under outdoor conditions and concluded that CdTe modules contribute to a high percentage of degradation when compared to crystalline technology in the humid continental climates. However, the degradation rates in crystalline silicon modules would behave differently with other climates. In Malvoni et al. (2017a), the performance of the PV system considering the degradation due to the PV technology and the operational weather conditions was investigated, concluding that the degradation rate estimation is helpful in reliability assessment of the photovoltaic system. The reported degradation rate for the Italian weather condition is between $0.15 \%$ /year and $0.54 \%$ /year over five years of outdoor exposure (Malvoni et al., 2018). Silvestre et al. (2016) studied the long term (five years) degradation analysis of silicon-based thin-film PV modules under Spanish continental climate conditions and observed that the CdTe module degrades higher with a value of $-4.45 \%$ /year. In (Kumar and Malvoni, 2019), a preliminary study quantified the four years degradation of a large-scale c-Si PV system in India to be between $0.30 \%$ /year and $0.17 \%$ /year. The summary of the 


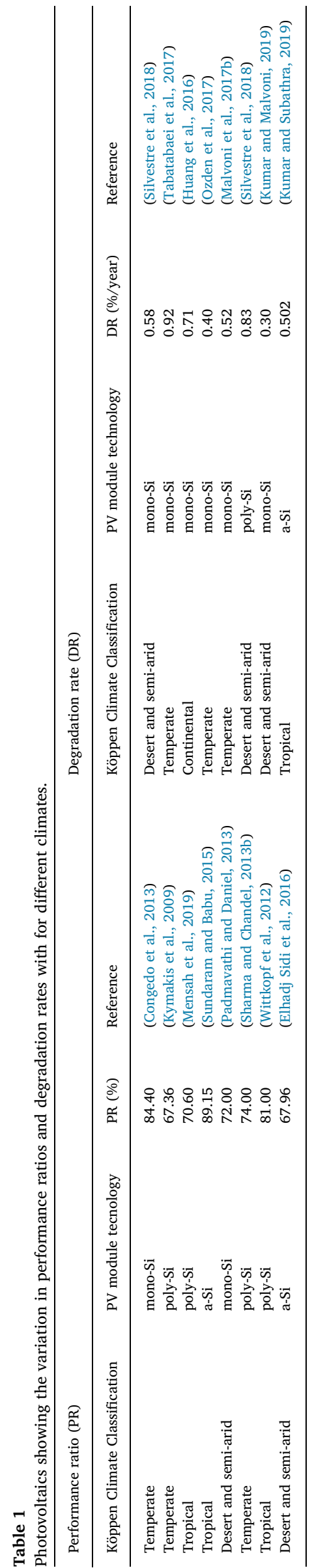

performance ratios, and degradation rates with climatic condition and PV technology specific are presented in Table 1.

Many other studies also reported the performance degradation estimated using different approaches. For example, the degradation of a $200 \mathrm{~kW}$ roof-integrated solar PV system located in Northern India was predicted by the PVsyst simulation tool. It was estimated between -0.6 to $-5 \%$ /year (Kumar et al., 2019a). Huang and Wang (2018) investigated the degradation of photovoltaic modules using simulated studies. Simulation mainly involves the study of the module characteristics that are influenced by environmental factors. The outcome of this research concluded the effects on short circuit current, power loss, optical degradation, decay in fill factor, among others. Huang and Wang's suggestions on observing these parameters would help the module designers to minimize their degradation influence over the module performance. In Kumar and Subathra (2019), three years ahead degradation rate of the a-Si PV plant in Southern Indian climates was estimated as $0.506 \%$ /year by using machine learning algorithms applied to the historical solar irradiance. Silvestre et al. (2018) studied the performance and degradation of crystalline silicon photovoltaic modules in the Saharan environment. They demonstrated the degradation rates using two methods one is the effective peak power of the PV modules, and the second is the temperature corrected performance ratio. This study involved continuous measurements and assessments for three years, and finally, they concluded that among the crystalline technologies, the HIT technology performs worse with a degradation rate of -1.53 to $1.92 \%$ /year. They also found that multi-crystalline and monocrystalline PV exhibits the degradation rates within the range of -0.74 to $0.83 \%$ /year and -0.58 to $0.79 \%$ /year, respectively, which are quite lower than HIT. Chantana et al. (2018) described the process of degradation observed in the multi-crystalline $\mathrm{Si}$ (mc-Si), singlecrystalline $\mathrm{Si}$ (sc-Si), hydrogenated amorphous $\mathrm{Si}(\mathrm{a}-\mathrm{Si})$, and a-Si/microcrystalline-Si tandem photovoltaic modules considering the influence of environmental factors such as irradiation intensity on a tilted surface, angle of incidence, average photon energy and module temperature. He concluded that the use of statistical multiple regression methods serves better in understanding the degradation process.

Even though many researchers are working on degradation problems of PV modules, a solution for solving or limiting the degradation is not yet proposed. The highly unstable operation of photovoltaic systems results in a performance variation with respect to weather parameters even though they are manufactured under one roof. Hence, it is vital to study the degradation of photovoltaic systems, primarily using long term performance data.

\section{Description of the utility-scale PV system}

The utility-scale solar PV power plant examined in this paper, is situated in Telangana, India. $\left(16.3^{\circ} \mathrm{N}, 77.7^{\circ} \mathrm{E}\right.$ and $401 \mathrm{~m}$ in altitude). The location is known for its semi-arid climatic condition and experiences significantly lower rainfall when compared to other parts within the state and the country. The weather condition of the PV plant location can be broadly divided into four seasons summer (Mar-Jun), monsoon (Jul-Sep), post-monsoon seasons (Oct-Nov), and winter (Dec-Feb). Here, the summers are hot and dry, with the temperature reaching around $40-48{ }^{\circ} \mathrm{C}$, while winters are quite chilly, with temperatures about $15-20{ }^{\circ} \mathrm{C}$. In all seasons, however, the adequate daylight is available and is very suitable for harnessing photovoltaic energy. The daily average solar resource availability in the installation site is around $5.29 \mathrm{kWh} / \mathrm{m}^{2} /$ day, with an average clearness index as 0.56 .

The state government has taken an enormous leap forward in the field of renewable energy, especially in photovoltaic installations (standalone and grid-connected). The Telangana government stands in third place in India with a total PV installation capacity of $2.6 \mathrm{GW}$ as of 31st October 2017 (Ministry of New and Renewable Energy, 2017). This initiative is taken to reduce the fossil fuel contribution to the energy mix. Besides, this laid a stable path for fulfilling the future energy needs of the state through green 


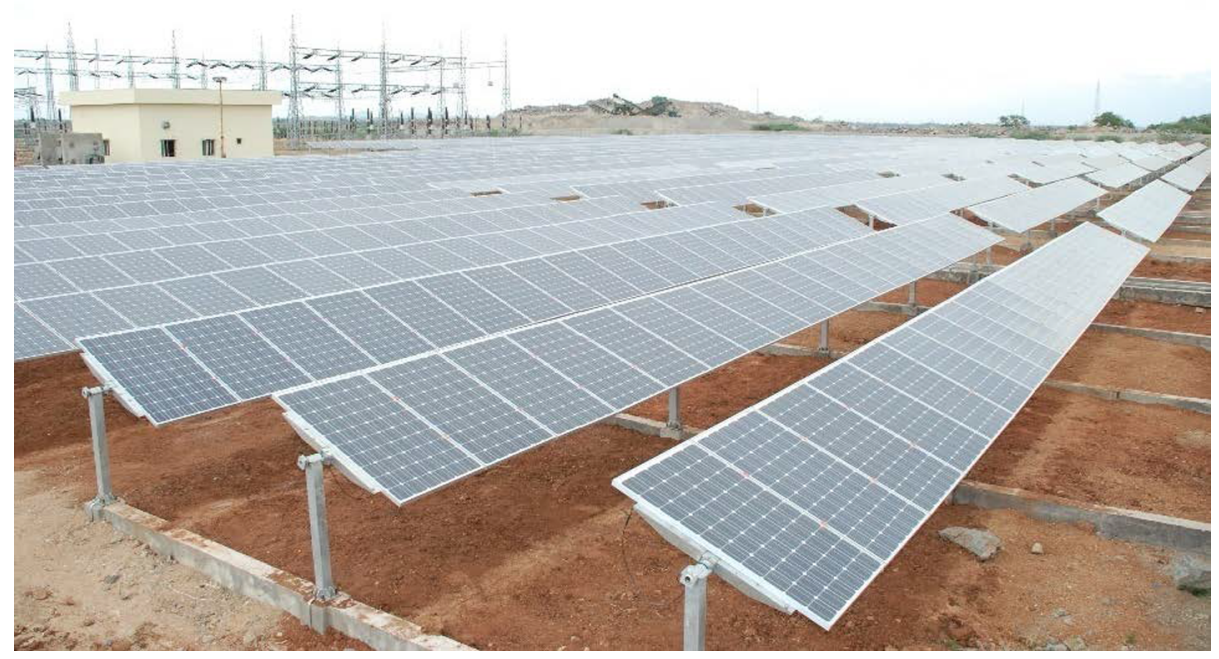

Fig. 1. PV modules on to the mounting structures in strings each consisting of $21 \mathrm{PV}$ modules.

energy, especially from renewable in the longer term. The solar PV power system analyzed in this paper was an initiative of Telangana State Power Generation Corporation Limited (TSGENCO) under the promotional incentives offered by the Ministry of New and Renewable Energy (MNRE), Government of India (GoI) under Jawaharlal Nehru National Solar Mission (JNNSM). The capacity of the power plant is $1 \mathrm{MWp}$ installed on an open land area. Apart from the state electricity agency, and MNRE, two other firms are involved in realizing this project. The M/S Photon Energy Systems Ltd, Hyderabad handles civil works related to the mounting structure layouts, erection of the modules, and other product delivery and supply details on EPC basis.

On the other hand, the work related to the tender document design and shortlisting of applicants for the product procurement is handled by the M/S IntelliDecs Pvt Ltd, Hyderabad, on a consultancy basis. All generated electricity from this utility-scale power plant is fed into the grid through the nearest substation. For feeding the energy into the grid, an agreement on the tariff (Rs./kWh) for 25 years is made, i.e., Rs.17.91, which is cumulative of Rs. 5.50 by state electricity board and generation-based incentives (GBI) of Rs. 12.41 by Indian Renewable Energy Development Agency Ltd. (IREDA). The plant understudy has a peak installed power rating of the $1 \mathrm{MWp}$, consists of $4284 \mathrm{PV}$ modules, each having a capacity of $235 \mathrm{KWp}$. All the modules are crystalline based connected in 204 parallel strings, and each string comprises 21 modules in series, as shown in Fig. 1.

The modules are installed in open rack configuration with a provision of adjusting the tilt as per the seasons, i.e., in summers $1^{\circ}$ and winters $31^{\circ}$. Here, each string of PV modules is connected to String Junction Box (SJB), and the PV array has 12 string monitoring units (SMU). Here such strings are connected to 4 DC combiner boxes (DCCB) before the output of PV modules is fed to the Main Junction Box (MJB).
Before the supply is fed into the inverter, the string DC nominal voltage is $630 \mathrm{~V}$. The maximum power for each string is $4.935 \mathrm{kWp}$, and each string monitoring unit is $88.83 \mathrm{~kW}$. From the MJB, the output of the PV array is connected to a maximum power point tracking (MPPT) enabled power conditioning unit (PCU). This is usually a DC-AC converter (inverter). Here, four inverters of THEIA make are used, each having a capacity of $250 \mathrm{kWp}$. The DC/AC ratio calculated by dividing the array capacity $(\mathrm{kWdc})$ to the inverter capacity $(\mathrm{kWac})$ is 1.01 .

At the output terminals of the inverter, a bi-directional energy counter is installed to record the inflow and outflow of energy in kWh. Finally, the output of $1 \mathrm{MW}_{\mathrm{P}} \mathrm{PV}$ system is connected to $11 \mathrm{kV}$ grid through 2 step-up power transformers of each having a capacity of $630 \mathrm{kVA}$, which is $300 \mathrm{~V} /$ $11 \mathrm{kV}$, which is further connected to $33 / 11 \mathrm{kV}$ Gadwal Substation. The studied utility-scale PV system schematic view is shown in Fig. 2, and a fully operational power plant is shown in Fig. 3.

The specifications of sub-components such as PV module, array configuration, mounting configuration, inverter, and power transformer are described in Tables 2, 3, 4, 5, and 6, respectively. For a better understanding of the system performance, a central monitoring unit (CMU) along with supervisory control and data acquisition (SCADA) system is installed. A weather data logging unit is also installed to monitor and record solar radiation, temperature, wind speed. The CMU records the output of the solar PV plant that is feeding into the grid.

\section{PV system performance parameters}

\subsection{Performance indexes}

Performance parameters of the solar PV system include final yield $\left(Y_{F}\right)$, system efficiency $\eta$, performance ratio (PR) and capacity factor

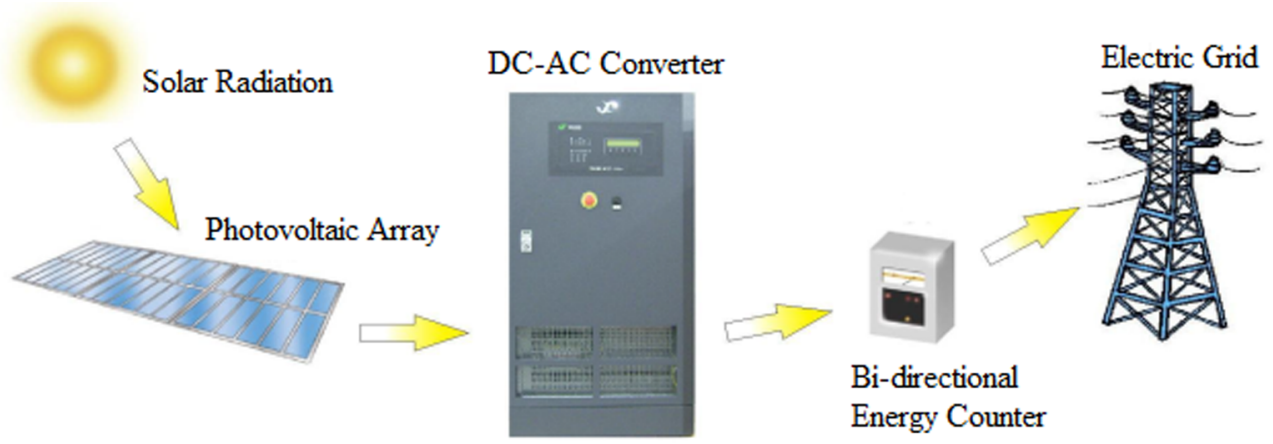

Fig. 2. Schematic view of the grid-connected solar power plant along with its components. 


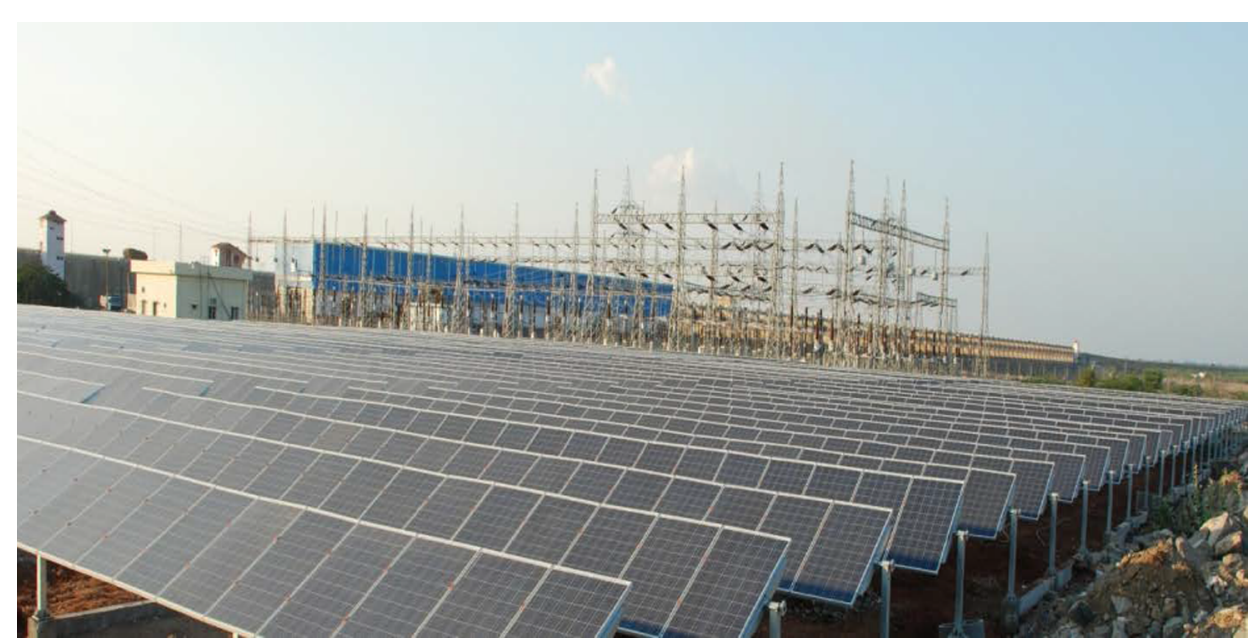

Fig. 3. Installed and fully operational $1 \mathrm{MWp}$ utility-scale solar PV plant at Revulapally (Village), Mahabubnagar (District), Telangana (State), India (Kumar et al., 2018).

Table 2

PV module specifications.

\begin{tabular}{ll}
\hline Parameter & Value with units \\
\hline PV technology & Mono-Crystalline \\
Make & Photon Energy \\
Maximum power & $235 \mathrm{Wp}$ \\
The voltage at maximum power & $30.68 \mathrm{Vdc}$ \\
Current at maximum power & $7.75 \mathrm{~A}$ \\
Open circuit voltage & $37.09 \mathrm{~V}$ \\
Short circuit current & $8.2 \mathrm{~A}$ \\
Maximum system voltage & $1000 \mathrm{Vdc}$ \\
Power tolerance & $\pm 5 \%$ \\
Efficiency & $14.6 \%$ \\
No. of cells in the module & 60 \\
Cell voltage & $0.5 \mathrm{Vdc}$ \\
Cell size (area) & $156 * 156 \mathrm{Sq} . \mathrm{m}$ \\
No. of bypass diodes & 3 \\
\hline
\end{tabular}

(CF), as defined by IEC 61724:1998 standard and in accordance to the Photovoltaic Power Systems Programme (PVPS) of the International Energy Agency (IEA) (IEC61724, 1998, IEA-PVPS, 2014, Woyte et al., 2014).

The final yield $\mathrm{Y}_{\mathrm{F}}$ is the relation between the electrical energy injected into the grid $\left(\mathrm{E}_{\mathrm{AC}}\right)$ by the solar PV plant and the installed nominal power $\left(\mathrm{P}_{\text {rated }}\right)$, as given by:

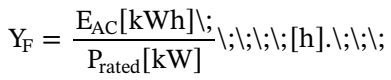

The system efficiency $\eta$ is expressed as the ratio of the electrical energy supplied to the power grid $\left(\mathrm{E}_{\mathrm{AC}}\right)$ and the solar energy $\left(\mathrm{H}_{\mathrm{POA}}\right)$, incident on the surface of the total modules (A). It is computed as:

Table 3

PV array specifications.

\begin{tabular}{ll}
\hline Parameter & Value with units \\
\hline Total no. of modules in the array & 4284 \\
No. of modules per structure (string) & 21 \\
No. of modules in series & 21 \\
No. of modules in parallel & 204 strings \\
No. of string monitoring units & 12 \\
No. of DC combiners boxes & 4 \\
String DC nominal voltage & $630 \mathrm{Vdc}$ \\
Maximum power for each string & $4.935 \mathrm{~kW}$ \\
Maximum power for each string monitoring unit & $88.83 \mathrm{~kW}$ \\
\hline
\end{tabular}

Table 4

Mounting structure details.

\begin{tabular}{ll}
\hline Parameter & Value with units \\
\hline Mounting & Fixed seasonal tilt \\
Material used & Mild steel with hot-dip galvanized \\
Summer tilt angle & $1^{\circ}$ \\
Winter tilt angle & $31^{\circ}$ \\
\hline
\end{tabular}

$\eta=\frac{E_{A C}[\mathrm{kWh}]}{H_{P O A}\left[\mathrm{kWh} / \mathrm{m}^{2}\right] * A\left[\mathrm{~m}^{2}\right]} * 100 \quad[\%]$.

The performance ratio $(\mathrm{PR})$ represents the ratio between the actual energy generated by the PV plant and the energy generated by the ideal PV without losses in the same conditions of the solar irradiance, as follows:

$P R=\frac{Y_{F}}{Y_{R}} * 100 \quad[\%]$.

The PR is one of the foremost parameters to assess the overall efficiency of PV systems, enabling the benchmarking of grid-connected PV systems of any power anywhere in the world.

The reference yield $\left(\mathrm{Y}_{\mathrm{R}}\right)$ is the total solar energy on the plane of array $\left(\mathrm{H}_{\mathrm{POA}}\right)$ related to the reference irradiance $\left(\mathrm{G}_{\mathrm{STC}}\right)\left(1000 \mathrm{~W} / \mathrm{m}^{2}\right)$ at

Table 5

Inverter specifications.

\begin{tabular}{ll}
\hline Parameter & Value with units \\
\hline Make & THEIA 250 TL inverter \\
No. of units & 4 \\
Rated capacity & $250 \mathrm{kWp}$ \\
Input voltage range & $450-820 \mathrm{Vdc}$ \\
Output voltage & $300 \mathrm{Vac}$ \\
Frequency & $40 \mathrm{~Hz}$ \\
Efficiency & $>98 \%$ \\
\hline
\end{tabular}

Table 6

Power transformers specifications.

\begin{tabular}{ll}
\hline Parameter & Value with units \\
\hline No. of step-up power transformers & 2 \\
Rated capacity & $630 \mathrm{kVA}$ \\
Voltage & $300 \mathrm{~V} / 11 \mathrm{kV}$ \\
Auxiliary transformer & $63 \mathrm{kVA}, 11 \mathrm{kV} / 425 \mathrm{~V}$
\end{tabular}


standard test conditions (STC), as given:

$Y_{R}=\frac{H_{P O A}\left[\mathrm{kWh} / \mathrm{m}^{2}\right]}{G_{S T C}\left[\mathrm{~kW} / \mathrm{m}^{2}\right]}[h]$.

The capacity factor (CF) expresses the ratio of the real annual electrical energy and the electrical energy that could be generated in the nominal power condition operating $24 \mathrm{~h}$ a day. The capacity factor is determined by:

$C F=\frac{E_{A C}[\mathrm{kWh}]}{P_{\text {rated }}[\mathrm{kW}] * 8760[\mathrm{~h}]} * 100 \quad[\%]$.

It is possible to refer to daily and monthly yield, efficiency, and performance ratio of the PV system by applying a suitable unit of the variable or by summing of the proper period. So, the daily AC electrical energy $\left(E_{A C, d}\right)$ and the monthly $A C$ electrical energy $\left(E_{A C, m}\right)$ can be used in Eq. (1) to determine daily and monthly final field (h/day and h/ month). In Eq. (4), if the solar irradiance on the plane of the array is related to daily $\left(\mathrm{H}_{\mathrm{POA}, \mathrm{d}}\right)$ or monthly values $\left(\mathrm{H}_{\mathrm{POA}, \mathrm{m}}\right)$, then the reference yield will be in $\mathrm{h}$ /day or $\mathrm{h} / \mathrm{month}$.

\section{Methods for the PV system degradation}

Statistical degradation methods for PV Systems are widely employed to estimate performance losses (Lindig et al., 2018). They enable us to extract the trend of performance time-series, so it is possible to quantify the degradation rate by assessing the slope of such a trend by applying linear regression (Phinikarides et al., 2014a).

Therefore, the annual degradation rate (DR) of the PV grid-connected system can be estimated by:

$D R=12 * \frac{a}{b} * 100[\%]$,

where $\mathrm{a}$ is the slope, and $\mathrm{b}$ is the intercept of the linear trend, according to the equation $Y=a X+b$, derived from the fitting of the performance ratio time-series in a statistical model.

To evaluate the quality of a fitted model, the standard errors and confidence intervals of the regression coefficients $a$ and $b$ are examined. For this reason, the coefficient covariance matrix (CM) is introduced. For any given random vector of elements, the CM gives the covariance between each pair of elements. CM is generally represented as a square matrix as follows (Weaver et al., 2013):

$C M=\left[\begin{array}{cc}\sigma_{b}^{2} & \sigma_{b} \sigma_{a} \\ \sigma_{a} \sigma_{b} & \sigma_{a}^{2}\end{array}\right]$.

The diagonal elements represent the variances $\left(\sigma_{i}^{2}\right)$ of the $\mathrm{i}^{\text {th }}$ coefficient. The standard error of the $\mathrm{i}^{\text {th }}$ coefficient $\left(\mathrm{SE}_{\mathrm{i}}\right)$ is defined as the square root of the corresponding variance as:

$S E_{i}=\sqrt{\sigma_{i}^{2}}$.

The coefficient confidence interval (CI) provides the range that the corresponding regression coefficient will be in with $100(1-\alpha) \%$ confidence. It is defined as

$C I=c_{i} \pm t_{\left(1-\frac{\alpha}{2}, N-p\right)} \times S E_{i}$,

where $\mathrm{c}_{\mathrm{i}} \backslash$; is the $\mathrm{i}^{\text {th }}$ coefficient estimated and $t_{\left(1-\frac{\alpha}{2}, N-p\right)}$ is the $100(1-\alpha / 2)$ percentile of $t$-distribution with $\mathrm{N}-\mathrm{p}$ degrees of freedom. $\mathrm{N}$ is the number of observations, and $\mathrm{p}$ is the number of regression coefficients.

The Root Mean Squared Error (RMSE) is also evaluated. It measures the average mismatch between each observation and the corresponding value fitted by the linear regression model. It is defined as

$R M S E=\sqrt{\frac{1}{N} \sum_{i=1}^{N}(x-\hat{x})^{2}}$, where $\mathrm{x}$ is the observed values and $\hat{x}$ is the predicted values.

Furthermore, the uncertainty associated with $\mathrm{DR}\left(\mathrm{u}_{\mathrm{DR}}\right)$ as defined by Eq. (6) can be determinate as follows (JCGM, 2008):

$u_{D R}=\sqrt{\left(\frac{\partial D R}{\partial a}\right)^{2} \times \sigma_{a}^{2}+\left(\frac{\partial D R}{\partial b}\right)^{2} \times \sigma_{b}^{2}}$,

where

$\frac{\partial D R}{\partial a}=\frac{12}{b}$,

$\frac{\partial D R}{\partial b}=-\frac{12 a}{b^{2}}$,

with $\sigma_{a}$ and $\sigma_{b}$ the standard deviations related to a and $\mathrm{b}$, respectively (Belluardo et al., 2015). Therefore, the $\sigma_{a}^{2}$ and $\sigma_{b}^{2}$ represent the variance of the fitting coefficients (Lindig et al., 2018).

In this study statistical methods applied to extract the PR trend are the linear least-squares regression (LLS), the classical seasonal decomposition (CSD), the Holt-Winters seasonal model (HW), and the seasonal and trend decomposition using loess (STL).

\subsection{Linear least-squares regression (LLS)}

The linear least-squares fitting technique is the most standard and straightforward method to fit measured data by using a linear regression that minimizes the summed square of residuals, given as the difference between the observed value and the fitted value (Bevington and Robinson, 1992). A first-degree polynomial, as provided in Eq. (14), is chosen as a linear model to fit the data observed for the PR at the time $t$ by using the linear least-squares method:

$\hat{y}=a t+b, \quad t=1, \ldots, n$.

Here $\hat{y}$ is the fitted value, $\mathrm{n}$ is the number of observations, $\mathrm{a}$ and $\mathrm{b}$ represents the coefficients of the linear model and, consequently the slope and the intercept of the trend line that fits the PR series in the monitored period.

\subsection{Classical seasonal decomposition (CSD)}

This method considers constant seasonal variations during the years, decreasing their effects on the fitting process. The CSD fits the data observed by applying the centered moving average concept to derive the trend component and the seasonal index of a time series (Makridakis et al., 1998; Phinikarides et al., 2014a; Phinikarides et al., 2014b; Phinikarides et al., 2015)

The additive CSD model is defined as shown in Eq. (15):

$\hat{y}=T_{t}+S_{t}+e_{t}, \quad t=1, \ldots, n$.

where $\hat{y}$ is the fitted value, $\mathrm{T}_{\mathrm{t}} \backslash$; is the trend component, $\mathrm{S}_{\mathrm{t}} \backslash$; is the seasonal component, $\mathrm{e}_{\mathrm{t}} \backslash$; is the residual component, and $\mathrm{n}$ is the number of observed data on the monitored period. The trend component $T_{t} \backslash$; is given by Eq. (16):

$T_{t}=\frac{1}{2}\left(\frac{1}{k} \sum_{i=t-m}^{t+m-1} y_{i}+\frac{1}{k} \sum_{i=t-m+1}^{t+m} y_{i}\right), t>m$.

$\mathrm{k}$ is 12 , as the months in a year represent the moving average order, $\mathrm{m}$ is the half-width of a moving average $(\mathrm{m}=\mathrm{k} / 2)$. To compute the degradation rate, Eq. (6) is applied to the trend component $\mathrm{T}_{\mathrm{t}}$.

\subsection{Holt-Winters' seasonal method (HW)}

The Holt-Winters seasonal method includes four equations as follows (Holt, 2004; Winters, 1960; Lindig et al., 2018).

$\hat{y}_{t+1}=l_{t}+b_{t}+s_{t-m+1}$, 
$l_{t}=\alpha\left(y_{t}-s_{t-m}\right)+(1-\alpha)\left(l_{t-1}+b_{t-1}\right)$,

$b_{t}=\beta\left(l_{t}-l_{t-1}\right)+(1-\beta) b_{t-1}$,

$s_{t}=\gamma\left(y_{t}-l_{t-1}-b_{t-1}\right)+(1-\gamma) s_{t-m}, \quad t=1, \ldots, n$,

where $l_{t}$ is the level, $b_{t} \backslash$; is the trend and $s_{t}$ is the seasonal component, with the corresponding smoothing parameters $\alpha, \beta$, and $\gamma$. m represents the seasonality frequency, e.g., for monthly data $\mathrm{m}$ is 12 . The smoothing parameters are determined by minimizing the mean absolute error (MAE). In the present work, such parameters are $\alpha=0.306$, $\beta=0.0003, \gamma=0.426$, and $\mathrm{MAE}=1.763$.

\subsection{Seasonal trend decomposition using loess (STL)}

STL is a very versatile and robust method for decomposition of time series, which is developed by (Cleveland et al., 1990). Like the additive CSD model, in the STL method, the time series is usually decomposed into three components, as follows in Eq. (21) (Phinikarides et al., 2013):

$\hat{y}=T_{t}+S_{t}+R_{t}, \quad t=1, \ldots, n$.

Here $\mathrm{T}_{\mathrm{t}}$ is the trend component, $\mathrm{S}_{\mathrm{t}} \backslash$; is the seasonal component, and $\mathrm{R}_{\mathrm{t}}$ is the residual component. The STL method uses a locally weighted linear regression in the data smoothing process. Like the moving average method, the smoothed data is estimated by using the neighboring points within the range.

\section{Results and discussion}

The performance of the PV system depends on the weather parameters that directly cause performance degradation. Performance degradation could vary depending on the life of the PV system. Hence its evaluation needs the monitoring facility and analysis of various performance parameters as per the IEC standards. Based on the monitored parameters, the performance ratio, which defines the quality of the PV system, is evaluated. The monitored performance ratio of the PV system is responsible for calculating the degradation rates. In this section, an analysis of the monitored performance results and evaluated degradation rates is done using four methods and considering the four years of operational data.

\subsection{Solar irradiance and energy outputs}

Monthly average of daily solar irradiance incident on the plane of PV array and energy outputs are discussed in this section. The lowest measured solar irradiance is in July $2013\left(4.20 \mathrm{kWh} / \mathrm{m}^{2} /\right.$ day $)$, and the highest is in February 2015 (7.13 $\mathrm{kWh} / \mathrm{m}^{2} /$ day $)$. In winter, solar irradiance varies from 5.47 to $6.99 \mathrm{kWh} / \mathrm{m}^{2} /$ day; in summer, it ranges between 5.74 and $7.13 \mathrm{kWh} / \mathrm{m}^{2} /$ day, and in the rainy season, it ranges between 4.20 and $6.41 \mathrm{kWh} / \mathrm{m}^{2} /$ day. Regarding the energy outputs, the lowest measured energy is in July 2013 (3476.88 $\mathrm{kWh} /$ day), and the highest is in February 2015 (5468.46 kWh/day). In winter, measured energy varies from 4909.42 to $5468.46 \mathrm{kWh}$ /day; in summer, it ranges between 4025.69 and $5415.84 \mathrm{kWh} /$ day, and in the rainy season, it ranges between 3476.68 and $4663.06 \mathrm{kWh} /$ day. Over 50 months, the monthly average of daily solar irradiance incident on the plane of PV array and energy outputs are depicted in Fig. 4.

The monthly average energy output increases linearly with the increase of daily solar irradiance incident on the plane of the PV array and shows a strong correlation $\left(\mathrm{R}^{2}=0.8097\right)$ with solar irradiance. The correlation between the monthly incident solar irradiance and energy outputs are shown in Fig. 5.

\subsection{Reference and final yields}

The reference yield is the amount of solar irradiance incident on the plane of PV array divided by the reference irradiance, i.e., $1000 \mathrm{~W} / \mathrm{m}^{2}$.

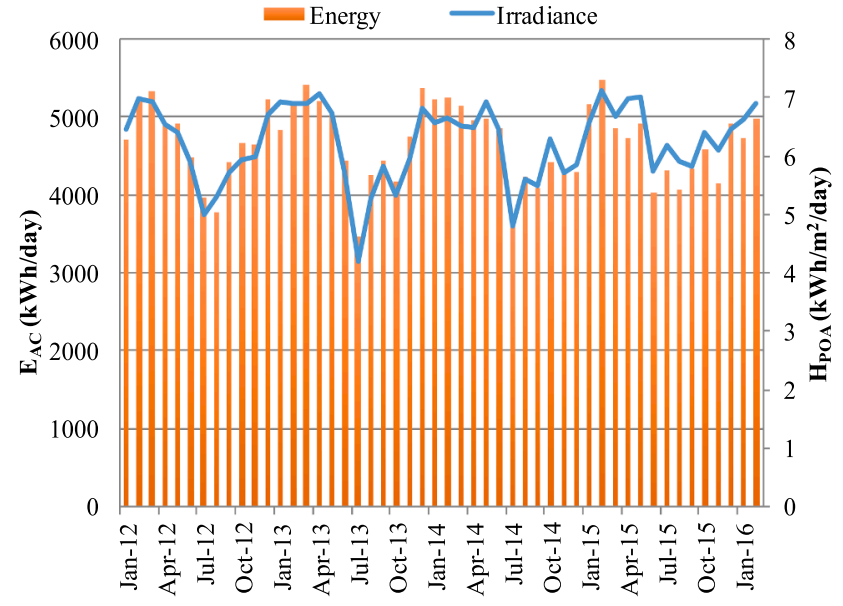

Fig. 4. Monthly average of daily solar irradiance incident on a PV array and energy outputs from the PV array.

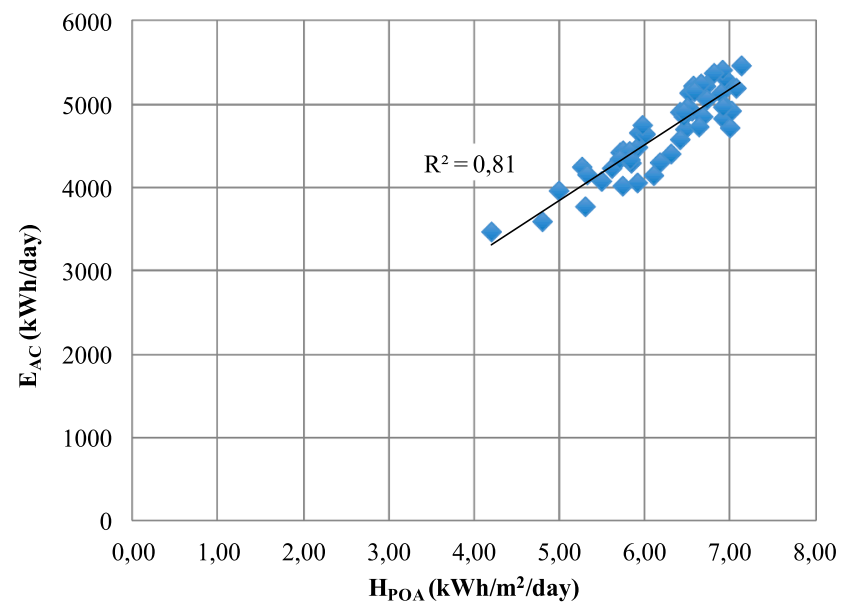

Fig. 5. Correlation between monthly average of daily solar irradiance and energy outputs.

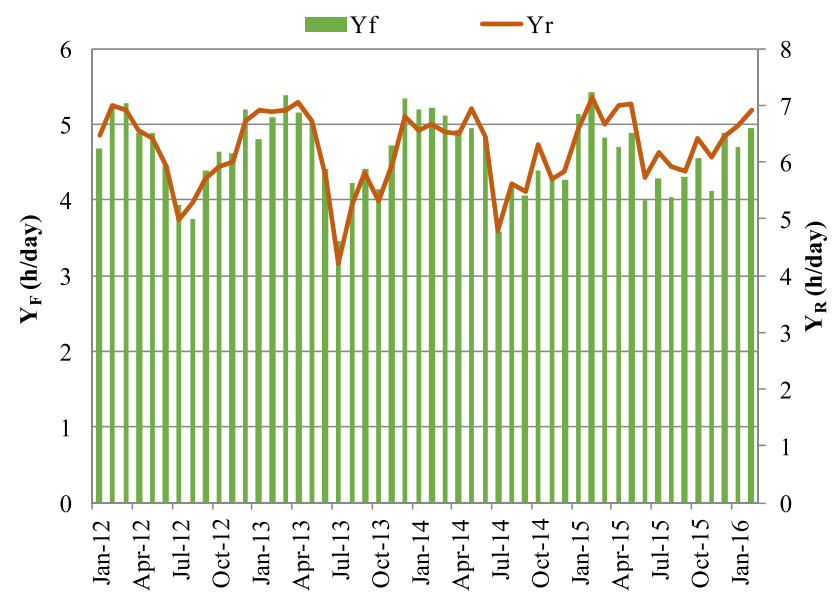

Fig. 6. Monthly average of daily reference and final yields of the utility-scale solar power plant.

It depends on the daily in-plane solar radiance. Higher reference yields are observed when there is high in-plane solar irradiance on the PV array. The monthly average daily reference yields vary from a minimum of $4.20 \mathrm{~h} /$ day into a maximum of $7.13 \mathrm{~h} /$ day in as seen in Fig. 6 . The average value over the 50 months of the observation period is $6.23 \mathrm{~h}$ /day. In winter reference yields vary from $5.70 \mathrm{~h}$ /day to 


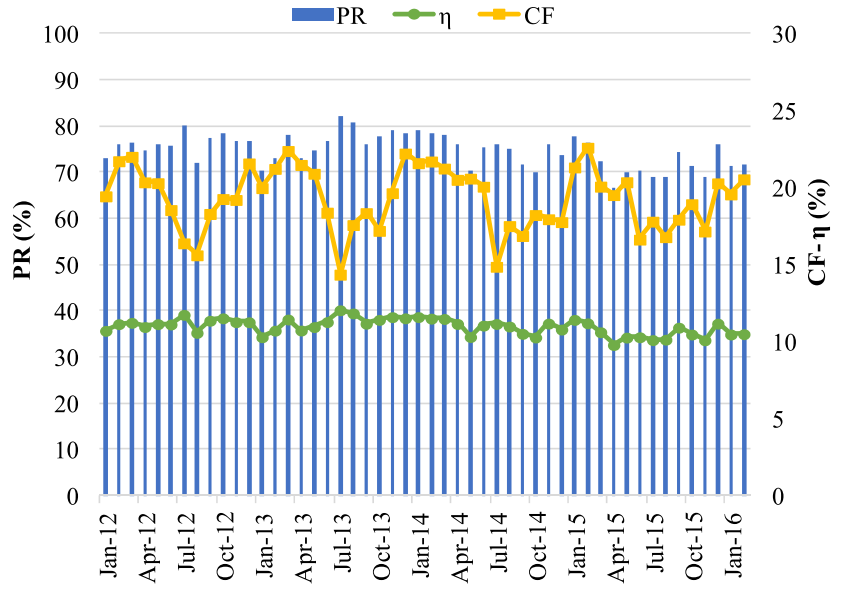

Fig. 7. Efficiency, capacity factor, and Performance ratio of $1 \mathrm{MWp}$ solar power plant in tropical semi-arid environments in India.

$7.13 \mathrm{~h} /$ day, in summer it ranges between 5.74 and $7.07 \mathrm{~h} /$ day, and in the rainy season, it ranges between 4.20 and $6.30 \mathrm{~h}$ /day. There is a similarity in the variation between the reference yield and final yield over the monitored period of 50 months, seen in Fig. 6. The monthly average daily final yields vary from a minimum of $3.45 \mathrm{~h} /$ day to a maximum of $5.43 \mathrm{~h} /$ day. The average final yield value over the 50 months of the observation period is $4.64 \mathrm{~h} /$ day. In winter, the final yields vary from 4.12 to $5.43 \mathrm{~h} /$ day; in summer, it ranges between 4.28 and $5.38 \mathrm{~h} /$ day, and in the rainy season, it ranges between 3.45 and $4.63 \mathrm{~h} /$ day. This variation in reference and final yields is because the monthly average in-plane solar insolation is found directly proportional to the in-plane solar insolation. The difference in variation between these two yields is observed to be within 0.18-0.33, with an average difference as 0.25 over the monitored period of 50 months. Final yields are lower when compared to the reference, and this is due to the influence of various weather parameters, which directly or indirectly affect the system performance.

\subsection{Efficiency and capacity factor}

The monthly average system efficiency varies from a minimum of $9.82 \%$ to a maximum of $12.08 \%$, as described in Fig. 7. Irrespective of the seasons, the average system efficiencies are observed as $11 \%$. For the winter season efficiency varies with a minimum of $10.13 \%$ and a maximum of $11.63 \%$, summer season form minimum of $10.32 \%$, and a maximum of $11.47 \%$ and in the rainy season from a minimum of $10.14 \%$ and a maximum of $11.78 \%$. The capacity factors (CF) are evaluated for the monitoring period of 50 months and reported in Fig. 7. The CF is reasonably maintained at an average value of $19.33 \%$ over 50 months, varying between a minimum of $14.39 \%$ and a maximum of $22.63 \%$.

Considering the seasonal influence, the CF exhibits a minimum value of $20.32 \%$ and a maximum value of $22.26 \%$ during the winter. In summer, the evaluated $\mathrm{CF}$ varies from a minimum value of $16.66 \%$ to a maximum value of $22.41 \%$, and in and in the rainy season, it ranges between 14.39 and $19.30 \%$. The capacity factors are observed to be in accordance with the final yield of the PV system.

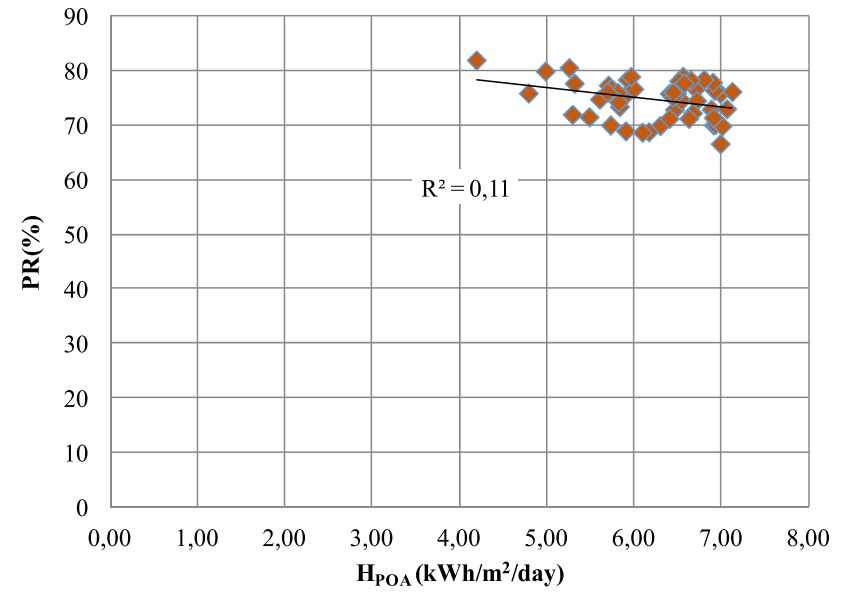

Fig. 8. Relationship between incident solar irradiance on the PV array and performance ratio of the PV array.

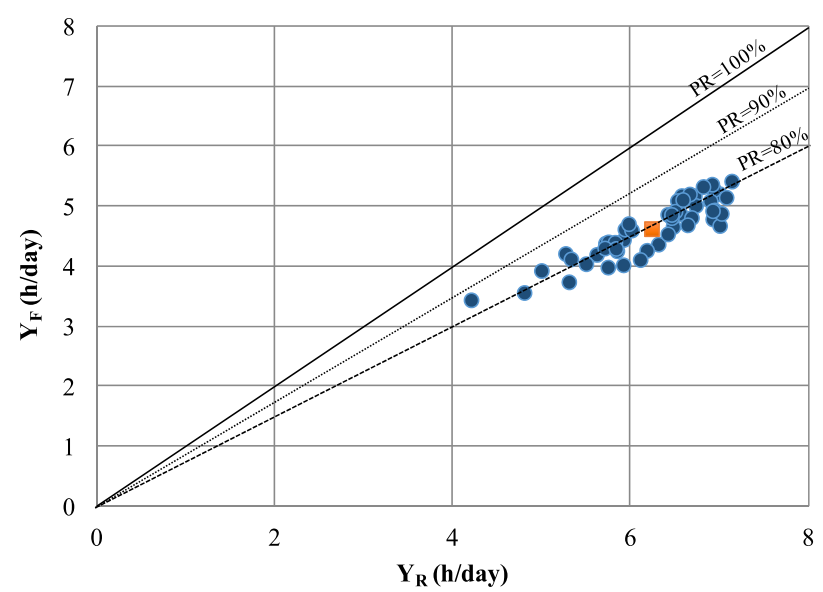

Fig. 9. Monthly performance ratio of $1 \mathrm{MWp}$ solar power plant represented as $\mathrm{Y}_{\mathrm{R}}$ (h/day) Vs. $\mathrm{Y}_{\mathrm{F}}$ (h/day).

\subsection{Performance ratio}

Monitoring the monthly average daily generated energy from the PV array is responsible for calculating the final yield, which largely depends on the quality factor of the PV plant, i.e., performance ratio (PR). The performance ratios evaluated for the monitoring period of 50 months is reported in Fig. 7. Considering the different seasons experienced by the PV array in study location, the PR is reasonably maintained at a constant measuring average value of $74.73 \%$ over 50 months, varying between a minimum of $66.70 \%$ and a maximum of $82.04 \%$. Considering the seasonal influence on the PV plant's overall performance, the PR exhibits a minimum value of $67.62 \%$ and a maximum value of $79.12 \%$ during the winter. In summer, the evaluated PR varies from a minimum value of $67.09 \%$ to a maximum value of $78.34 \%$, and in the rainy season, it ranges between 68.31 and $82.25 \%$. PR values over the 50 months of monitoring duration are tabulated in Table 7, separating them for each year.

Table 7

Performance ratios for the monitored period.

\begin{tabular}{|c|c|c|c|c|c|c|c|c|c|c|c|c|}
\hline PR (\%) & Jan & Feb & Mar & Apr & May & Jun & Jul & Aug & Sep & Oct & Nov & Dec \\
\hline 2012 & 72.2 & 74.7 & 76.4 & 74.7 & 76.1 & 75.4 & 79.0 & 70.9 & 77.0 & 78.1 & 76.9 & 77.3 \\
\hline 2013 & 69.4 & 74.1 & 77.9 & 73.1 & 72.3 & 77.0 & 82.2 & 80.3 & 75.9 & 77.7 & 79.1 & 78.5 \\
\hline 2014 & 79.1 & 78.4 & 78.3 & 75.9 & 71.4 & 74.8 & 74.6 & 75.0 & 73.9 & 69.5 & 75.7 & 73.2 \\
\hline 2015 & 77.9 & 76.2 & 72.3 & 67.1 & 69.8 & 67.4 & 69.3 & 68.3 & 74.0 & 71.0 & 67.6 & 75.6 \\
\hline
\end{tabular}


Table 8

Comparative performance of grid-connected large PV systems.

\begin{tabular}{|c|c|c|c|c|c|c|c|c|c|}
\hline Location & & LAT $\left({ }^{\circ} \mathrm{N}\right)$ & LOG $\left({ }^{\circ} \mathrm{W}\right)$ & $\begin{array}{l}\text { Köppen Climate } \\
\text { Classification }\end{array}$ & Power $(\mathrm{kW})$ & $\begin{array}{l}\text { PV module } \\
\text { tecnology }\end{array}$ & $\begin{array}{l}\mathrm{Y}_{\mathrm{F}}(\mathrm{h} / \\
\text { day) }\end{array}$ & PR (\%) & Reference \\
\hline Lecce & Italy & 40.35 & 18.17 & Temperate & 960 & mono-Si & 3.80 & 84.40 & (Congedo et al., 2013) \\
\hline Xirolimni & Greece & 35.12 & 26.06 & Temperate & 171.36 & poly-Si & 3.66 & 67.36 & (Kymakis et al., 2009) \\
\hline Jaen & Spain & 37.73 & -3.78 & Temperate & 200 & mono-Si & 2.74 & 65.00 & (Drif et al., 2007) \\
\hline Navrongo & Ghana & 10.88 & -1.1 & Tropical & 2500 & poly-Si & & 70.60 & (Mensah et al., 2019) \\
\hline Sivagangai & India & 9.48 & 78.27 & Tropical & 5000 & $\mathrm{a}-\mathrm{Si}$ & 4.81 & 89.15 & (Sundaram and Babu, 2015) \\
\hline Revulapally & India & 16.3 & 77.7 & Tropical & 1000 & mono-Si & 4.64 & 74.73 & Present Study \\
\hline Ramagundam & India & 18.75 & 79.46 & Tropical & 10,000 & poly-Si & 3.52 & 86.12 & $\begin{array}{l}\text { (Shiva Kumar and Sudhakar, } \\
\text { 2015) }\end{array}$ \\
\hline Karnataka & India & 12.53 & 78.09 & Desert and semi-arid & 3000 & mono-Si & 3.73 & 72.00 & (Padmavathi and Daniel, 2013) \\
\hline Roorkee & India & 29.87 & 77.88 & Temperate & 1816 & mono-Si & 1.85 & 59.94 & (Pundir et al., 2016) \\
\hline Bhopal & India & 23.16 & 77.36 & Temperate & 142.5 & poly-Si & 3.02 & 71.60 & (Shukla et al., 2016) \\
\hline Khatkar-Kalan & India & 31.16 & 76.02 & Temperate & 190 & poly-Si & 2.15 & 74.00 & (Sharma and Chandel, 2013b) \\
\hline Singapore & Malaysia & 1.4 & 104 & Tropical & 142.5 & poly-Si & 3.12 & 81.00 & (Wittkopf et al., 2012) \\
\hline Nouakchott & Mauritania & 18.15 & -15.98 & Desert and semi-arid & 954.72 & $\mathrm{a}-\mathrm{Si}$ & 4.27 & 67.96 & (Elhadj Sidi et al., 2016) \\
\hline Mae Hong Son & Thailand & 19.18 & 97.58 & Tropical & 500 & poly-Si & 3.45 & 80.00 & (Chokmaviroj et al., 2006) \\
\hline
\end{tabular}

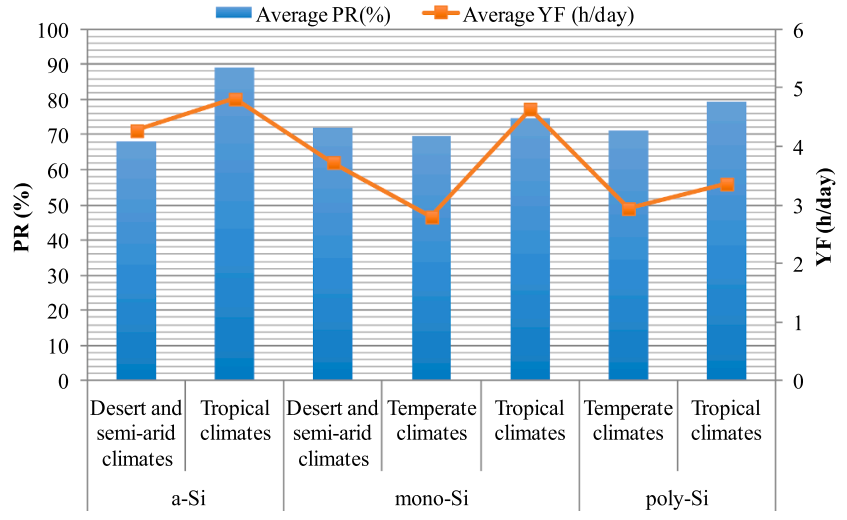

Fig. 10. Comparative performance studies - Average PR and YF for different climate conditions and PV module technologies.

The performance of the PV system is slightly higher in rainy periods followed by winter and, lastly, by summer periods. The variation in solar irradiance patterns and high ambient temperature in summer, results in higher module temperatures and, consequently, higher performance degradation. The relationship between the performance ratio and the monthly average of daily solar irradiance incident on the plane of the photovoltaic array shows a strong correlation.

The correlation between the monthly incident solar irradiance and performance ratios are shown in Fig. 8. By knowing the PR values, it is easy to identify the occurrences of various problems in the photovoltaic systems, especially the degradation rates. The lower PR generally indicates problems with the PV system, and they can be system losses due to the failure of some components and even failures of the PV plant design.

Even if PV systems perform with average PR of $67-82 \%$ in general, high PRs suggest that the plant is working near the rated power. The relationship between $Y_{F}$ and $Y_{R}$, as plotted in Fig. 9 shows clearly the effective operating conditions. Close to PR at about $80 \%$ demonstrates that the PV plant has not been affected by consistent failures, considering that PRs for all months is close to the linear trend of $80 \%$.

Table 8 presents performance indicators for the different PV plants with nominal power higher than $100 \mathrm{~kW}$. As shown in Fig. 10 the average PRs for the different technologies are found as 78,56 (a-Si), $71,21 \%$ (mono-Si), and 75,81 (poly-Si) with the highest PR in Tropical climates, according to the Köppen climate classification (Rubel and Kottek, 2010).

Annual average PR of the present studied PV plant over the four years of operation ranges from 71.37 to $76.46 \%$. Compared to PV power plants in other sites of India, the current PV plant showed a higher PR example 72\% for Karnataka (Padmavathi and Daniel, 2013), $71.6 \%$ for Bhopal (Shukla et al., 2016), 59.9\% for Roorkee (Pundir et al., 2016) and relatively close for the system in Khatkar-Kalan with 74\% (Sharma and Chandel, 2013b), underperforming in comparison to $89.15 \%$ for Sivagangai (Sundaram and Babu, 2015) and $86.12 \%$ for Ramagundam (Shiva Kumar and Sudhakar, 2015). When compared to other installed large PV systems in other sites of the world, it can be seen in Fig. 11, that the PR of the present PV plant (blue sphere) is in accordance with the collected studies for latitudes between $1.4^{\circ} \mathrm{N}$ and $4^{\prime} .35^{\circ} \mathrm{N}$, with a mean value of $74.6 \%$. Within the investigated studies, it is noted that PV plants with higher performance below $25^{\circ} \mathrm{N}$ can be found, including our PV system. The final yield for the investigated 1
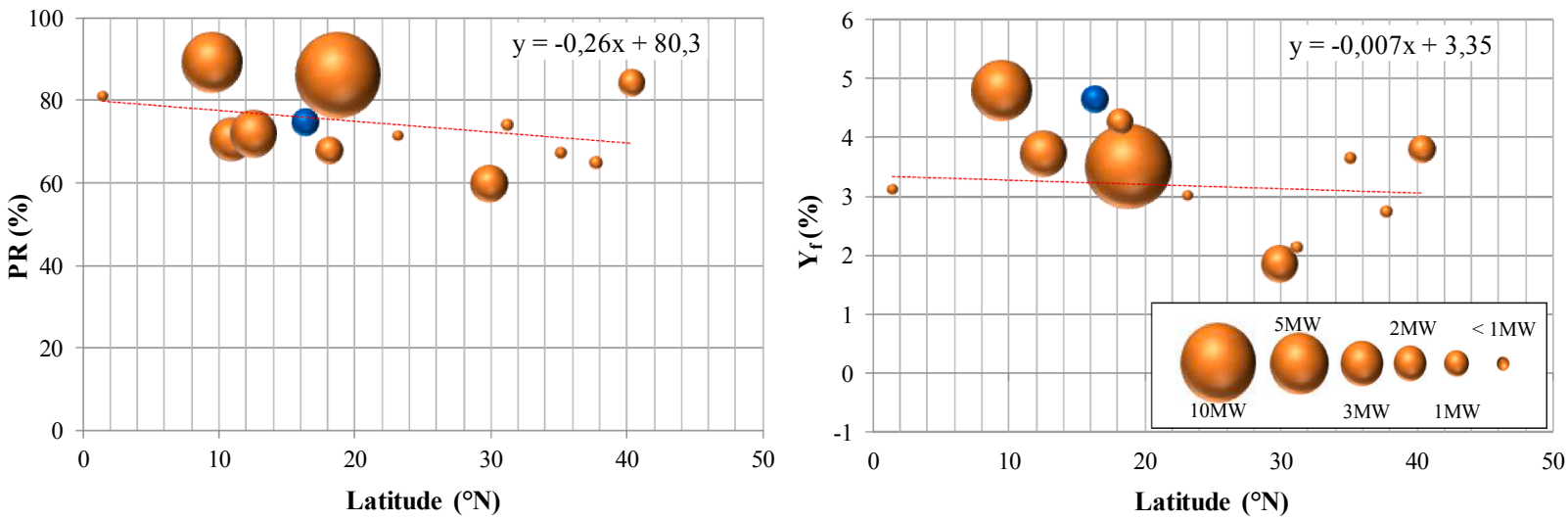

Fig. 11. Comparative performance studies - PR and $Y_{F}$ for different latitudes and installed capacity. 

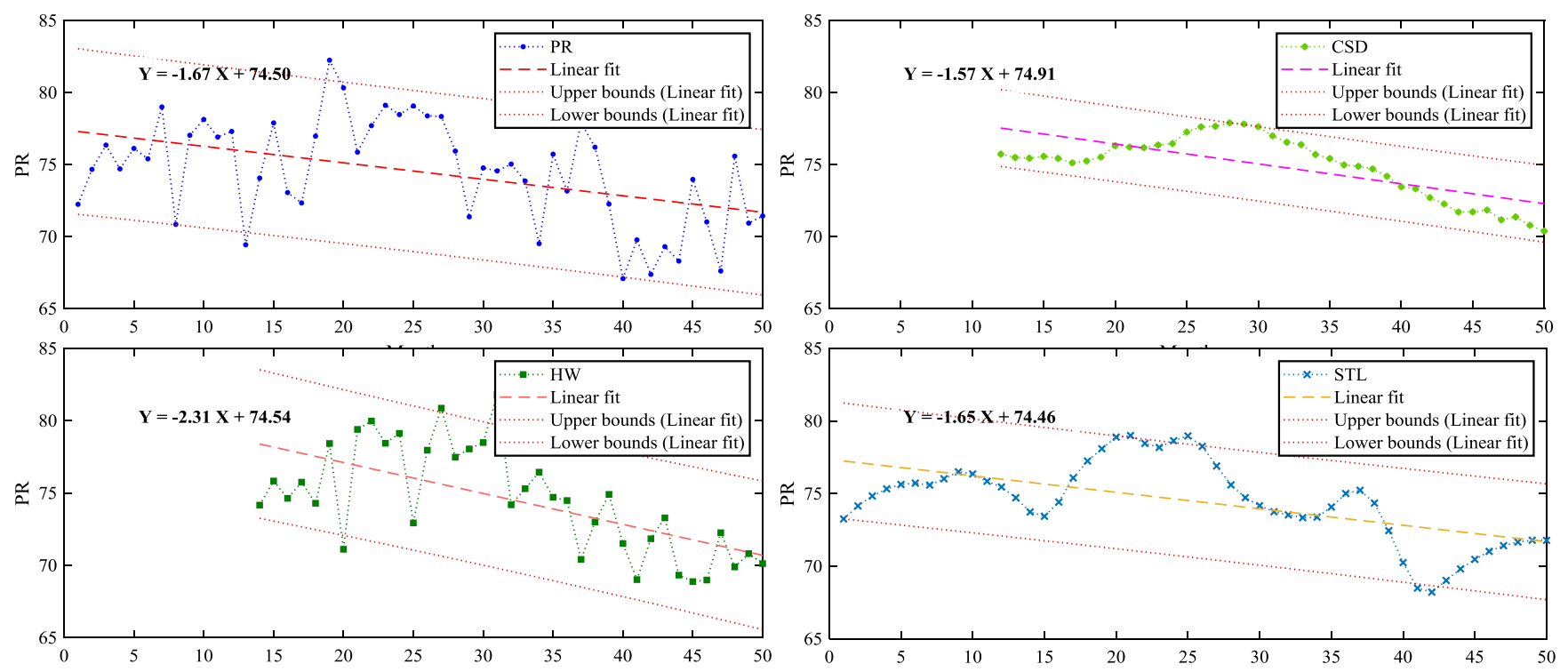

Fig. 12. Time series decomposition of performance ratio and related linear curve fitting.

Table 9

Coefficient standard error, coefficient confidence intervals, and RMSE.

\begin{tabular}{|c|c|c|c|c|c|}
\hline Statistical method & Coefficient & Coefficient value (\%) & SE (\%) & 95\% confidence bounds (\%) & RMSE (\%) \\
\hline \multirow[t]{2}{*}{ LLS } & a & -1.67 & 0.03 & $-2.62,-0.72$ & 3.30 \\
\hline & $\mathrm{b}$ & 74.50 & 0.95 & $73.56,75.44$ & \\
\hline \multirow[t]{2}{*}{ CSD } & $\mathrm{a}$ & -1.57 & 0.02 & $-2.07,-1.078$ & 1.51 \\
\hline & $\mathrm{b}$ & 74.91 & 0.71 & $74.42,75.4$ & \\
\hline \multirow[t]{2}{*}{ HW } & a & -2.31 & 0.04 & $-3.29,-1.33$ & 2.90 \\
\hline & $\mathrm{b}$ & 74.54 & 1.50 & $73.58,75.51$ & \\
\hline \multirow[t]{2}{*}{ STL } & a & -1.65 & 0.02 & $-2.312,-0.99$ & 2.30 \\
\hline & $\mathrm{b}$ & 74.46 & 0.66 & 73.81, 75.12 & \\
\hline
\end{tabular}

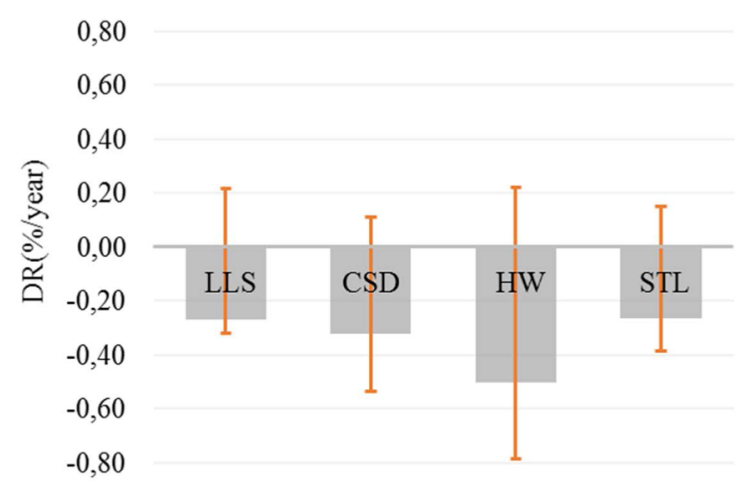

Fig. 13. Annual degradation rate and the uncertainty by applying linear fitting on PR time series (LLS) and trends from CSD, HW, and STL method.

MWp solar PV plant was found higher when compared to the average value (i.e., $3.44 \mathrm{~h} /$ day). This is true in the case of large PV plants, as per the Eq. (1), $Y_{F}$ represents the generated energy normalized by the installed capacity. Therefore, $\mathrm{Y}_{\mathrm{F}}$ should be high for large plants.

In Fig. 11 the size of the spheres represents the nominal power of each plant. A high $\mathrm{Y}_{\mathrm{F}}$ is also noted for smaller PV plants. This implies that failures could affect some of the considered PV systems during the operating condition. Furthermore, this ranks the current PV system at the top of the performance.

\subsection{Degradation analysis}

The degradation analysis of a 4-year field exposed utility-scale crystalline silicon PV system is carried out. Fig. 12 shows the PR time series and the corresponding decomposition by applying four statistical methods LLS, CSD, HW, and STL, as described in Section 5 . The equation $Y=a * X+b$ was derived from such linear curve fitting of the performance ratio time-series in order to extract the coefficients $a$ and $b$ as shown in Fig. 12, in which the 95\% confidence intervals are also illustrated.

Table 9 depicts the coefficient estimates, the corresponding standard errors, and confidence intervals. The highest errors are in the estimation of the intercept of the linear trend $b$ up to 1.50 for the HW model. However, the LLS model exhibits the worst performance with an RMSE of 3.30. The RMSE also demonstrates the best fitting for the CSD method.

The annual degradation rate and the associated uncertainty, according to Eqs. (6) and (11), respectively, are plotted in Fig. 13. The estimated DR is about $-0.27 \%$ year for STL and LLS that shows higher uncertainty $(0.22 \%$ /year) than STL $(0.15 \%$ /year). In the case of the $\mathrm{CSD}$, the DR is $-0.32 \%$ /year and the lowest uncertainty (0.11\%/year),

Table 10

Estimated annual degradation rates using four different methods.

\begin{tabular}{|c|c|c|c|c|}
\hline & LLS & CSD & HW & STL \\
\hline Degradation (\%/year) & $-0.27 \pm 0.22$ & $-0.32 \pm 0.11$ & $-0.50 \pm 0.22$ & $-0.27 \pm 0.15$ \\
\hline
\end{tabular}


Table 11

Comparative degradation of mono-Si PV systems computed with different methods.

\begin{tabular}{|c|c|c|c|c|c|}
\hline Reference & Location & Köppen Climate Classification & Outdoor exposure period (months) & DR (\%/year) & Method \\
\hline \multicolumn{6}{|l|}{ (Silvestre et al., 2018) } \\
\hline & Saida, Algeria & Desert and semi-arid & 24 & 0.58 & LSS \\
\hline (Tabatabaei et al., 2017) & Alkmaar, Netherlands & Temperate & 44 & 0.92 & STL \\
\hline \multirow[t]{2}{*}{ (Malvoni et al., 2017b) } & Lecce, Italy & Temperate & 43 & 0.52 & LSS \\
\hline & & & & 1.48 & CSD \\
\hline \multirow[t]{4}{*}{ (Lindig et al., 2018) } & Bolzano, Italy & Continental & 84 & & \\
\hline & & & & 0.73 & CSD \\
\hline & & & & 0.57 & HW \\
\hline & & & & 0.53 & STL \\
\hline \multirow[t]{2}{*}{ (Makrides et al., 2014) } & Nicosia, Cyprus & Desert and semi-arid & - & 0.62 & LSS \\
\hline & & & & 1.04 & CSD \\
\hline (Ishii et al., 2011) & Tsukuba, Japan & Temperate & 36 & 2.35 & LSS \\
\hline (Huang et al., 2016) & Golden, CO, USA & Continental & 60 & 0.71 & CSD \\
\hline (Ozden et al., 2017) & Ankara, Turkey & Temperate & 44 & 0.40 & LSS \\
\hline \multirow[t]{4}{*}{ Present study } & Mahabubnagar, India & Tropical & 50 & 0.27 & LSS \\
\hline & & & & 0.31 & CSD \\
\hline & & & & 0.48 & HW \\
\hline & & & & 0.26 & STL \\
\hline
\end{tabular}

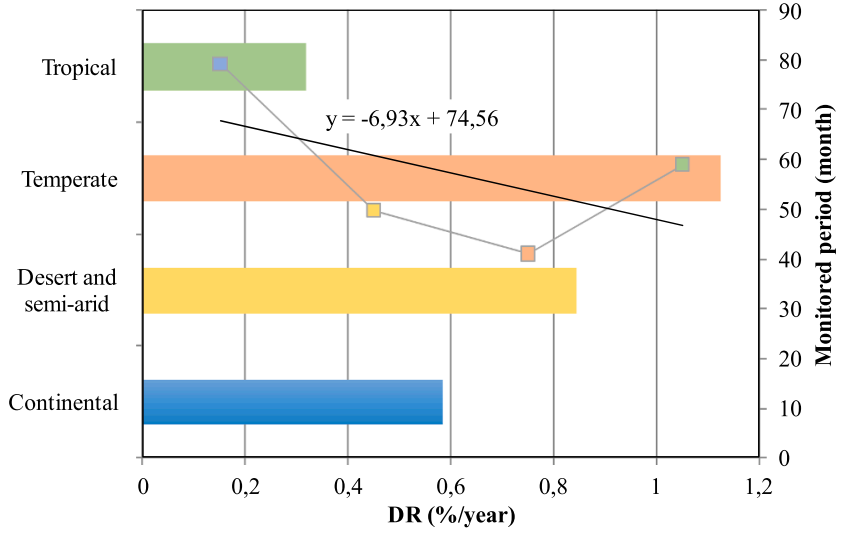

Fig. 14. Comparison of PV degradation studies as per different climate conditions.

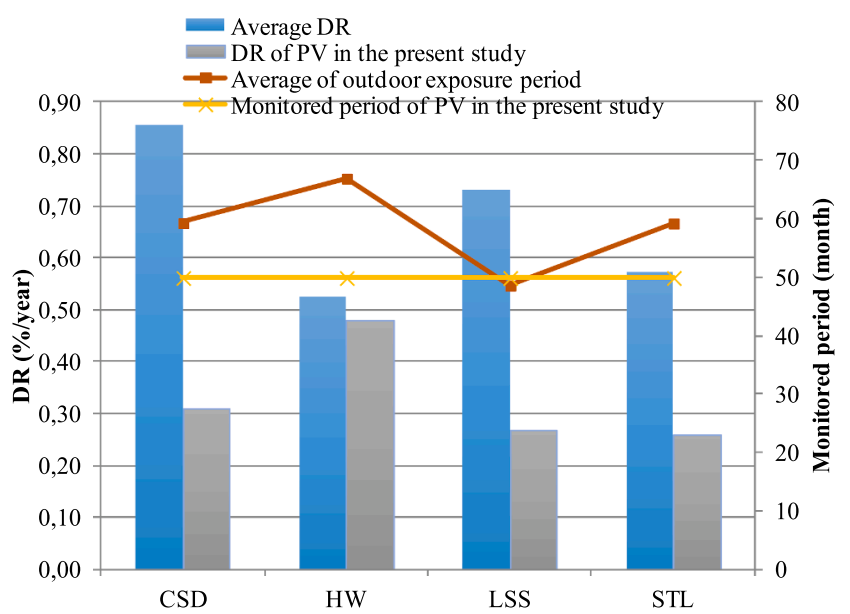

Fig. 15. Comparison of PV degradation studies with respect to various DR evaluation methods.

while HW gives a DR of $-0.50 \% /$ year and uncertainty of $0.22 \%$ /year. It is concluded that HW returns the worst degradation rate with the highest uncertainty. The STL outperforms all methods, providing the lowest DR with high accuracy, see in Table 10.

In the literature, several studies on PV module degradation can be fund. Different approaches are applied to investigate the performance losses. Table 11 shows the comparison for the degradation of mono-Si
PV systems in various locations resulting from previous studies, in which different fitting methods of PR evaluate the degradation rate.

The nine PV plants investigated present a DR between a minimum of $0.26 \%$ /year and a maximum of $2.3 \%$ /year with an average of $0.71 \%$ / year. Fig. 14 depicts the degradation rate according to the Köppen climate classification. In high-temperature climates, PV plants show more evident degradation mechanisms (1.13\%/year). Moderate performance losses can be founded in Continental $(0.58 \%$ /year) and Desert climates $(0.75 \% /$ year). The Tropical climate supports the lowest DR of $0.33 \% /$ year that is the case for the investigated system.

On the other side, the degradation depends on the monitored period considered to compute DR that was 56 months for the investigated works. The shortest monitored period is for Temperate climate (42 months), and the longest one is 79 months in Continental climates. The correlation between the time period and the DR demonstrates (Fig. 14) when the monitored period increases the degradation decreases (negative coefficient of the linear regression). Therefore, according to the climate classification and outdoor exposure period, with a DR of $0.33 \%$ /year and a monitored period of 50 months, the degradation of the PV system under study shows good agreement with the DR found in the literature.

From the collection of the degradation studies as in Table 11, it is noted that the LSS (7 studies) and CSD (5 studies) are the methods most employed in literature to estimate degradation. The LSS method estimates lower DR $(0.73 \%$ /year) than the CSD method ( $0.85 \%$ /year). The HW $(0.53 \% /$ year $)$ and STL $(0.57 \% /$ year) methods seem to underestimate the degradation with respect to the mean value of $0.71 \%$ /year. For the current PV plant, four methods used to determinate the degradation return lower DRs than the corresponding mean values (Fig. 15).

\section{Conclusion}

In this study, the performance and degradation of the $1 \mathrm{MW}_{\mathrm{P}}$ utilityscale PV system in Telangana State, India, was investigated in January 2012 - February 2016 period, according to the standard IEC 61724. The study contributes to the performance assessment of large-scale PV systems located in the Tropical semi-arid climate.

The monthly average daily reference yield is $6.23 \mathrm{~h} /$ day, and the final yield is found to be of $4.64 \mathrm{~h} /$ day. The system efficiency and capacity factors are $11.02 \%$ and $19.30 \%$, respectively. The performance ratio of a PV system is $74.73 \%$.

The final yield and the performance ratio are compared with the results of PV power plants in other sites of India, demonstrating a good performance of the $1 \mathrm{MW}_{\mathrm{P}} \mathrm{PV}$ systems. A comparative analysis with PV 
plants in different climate conditions confirms higher performance for the PV systems at lower latitudes. However, low final yields for PV plants located too low latitude can mean failures during the operating condition.

Furthermore, the degradation of the utility-scale PV power plant is also assessed. To the best of the author's knowledge, there are not contributions regarding the degradation analysis of $\mathrm{PV}$ power systems located in India using statistical methods.

The LLS, CSD, HW, and STL methods are applied to the time series of performance ratio, and the degradation rate is estimated as $0.27 \pm 0.22 \%$ /year, $0.32 \pm 0.11 \% /$ year, $0.50 \pm 0.22 \% /$ year, and $0.27 \pm 0.15 \% /$ year respectively. The uncertainty investigation demonstrates that LLS and HW methods return a DR with lower accuracy $(0.22 \%)$ than CSD $(0.11 \%)$ and STL $(0.15 \%)$ methods. However, the HW gives the highest degradation rate with the highest uncertainty, while the STL provides the lowest DR with high accuracy. A comparison of degradation studies from the literature for mono-crystalline module technology in different climate conditions is also presented. The degradation rate of the existing PV plant is in the range of $0.26-0.48 \%$ / year showing good agreement with the degradation results gathered by nine PV plants located in different climates. The investigated DRs, computed over a mean monitored 56 months, varies between a minimum of 0.26 and a maximum of $2.3 \%$ /year with a low value in Tropical (0.33\%/year) and more evident degradation mechanisms (1.13\%/year) in Temperate climates. The current PV plant presents DRs lower than the average values $(0.53-0.85 \%$ /year) obtained by the collected studies. However, the difference, recognized from the comparison analysis and due to different climate conditions, various time periods considered to quantify the degradation as well as several methods for the computing of the derate, highlight that standardized procedures should be in place to enable a degradation comparison of different PV systems in the same way as already done for the performance ratio.

\section{Declaration of Competing Interest}

The authors declare that they have no known competing financial interests or personal relationships that could have appeared to influence the work reported in this paper.

\section{Acknowledgment}

The analysis presented in this study received funding from the European Union's Horizon 2020 research and innovation programme under the Marie Skłodowska-Curie grant agreement No 799835. The authors would like to thank the "Telangana State Power Generation Corporation Limited (TSGENCO)," "M/S. Photon Energy Systems Ltd.", "M/S IntelliDecs Pvt Ltd.," for bringing the project into reality. The authors would also like to extend their gratitude to the technicians at the plant site for their excellent support in providing the data.

\section{References}

Belluardo, G., Ingenhoven, P. and Moser, D., 2013. Medium-term degradation of different photovoltaic technologies under outdoor conditions in Alpine area. Presented at the PVSEC 2013.

Belluardo, G., Ingenhoven, P., Sparber, W., Wagner, J., Weihs, P., Moser, D., 2015. Novel method for the improvement in the evaluation of outdoor performance loss rate in different PV technologies and comparison with two other methods. Sol. Energy 117, 139-152. https://doi.org/10.1016/j.solener.2015.04.030.

Bevington, P.R., Robinson, D.K., 1992. Error Data Reduction and Error Analysis for the Physical Sciences, McGraw-Hill Higher Education. https://doi.org/10.1063/1. 4823194.

Bouraiou, A., Hamouda, M., Chaker, A., Mostefaoui, M., Lachtar, S., Sadok, M., Boutasseta, N., Othmani, M., Issam, A., 2015. Analysis and evaluation of the impact of climatic conditions on the photovoltaic modules performance in the desert environment. Energy Convers. Manage. 106, 1345-1355. https://doi.org/10.1016/j. enconman.2015.10.073.

Bridge To India, 2017. India's Solar Handbook.
Chandel, S.S., Nagaraju Naik, M., Sharma, V., Chandel, R., 2015. Degradation analysis of 28 year field exposed mono-c-Si photovoltaic modules of a direct coupled solar water pumping system in western Himalayan region of India. Renew. Energy 78, 193-202. https://doi.org/10.1016/J.RENENE.2015.01.015.

Chantana, J., Kawano, Y., Kamei, A., Minemoto, T., 2018. Description of degradation of output performance for photovoltaic modules by multiple regression analysis based on environmental factors. Optik.

Choi, S., Ishii, T., Sato, R., Chiba, Y., Masuda, A., 2018. Performance degradation due to outdoor exposure and seasonal variation in amorphous silicon photovoltaic modules. Thin Solid Films 661, 116-121. https://doi.org/10.1016/j.tsf.2018.07.017.

Chokmaviroj, S., Wattanapong, R., Suchart, Y., 2006. Performance of a 500 kWP grid connected photovoltaic system at Mae Hong Son Province, Thailand. Renew. Energy 31, 19-28. https://doi.org/10.1016/J.RENENE. 2005.03.004.

Chattopadhyay, S., 2016. All-India Survey of Photovoltaic Module Reliability: 2016. Nat. Centre Photovolt. Res Educ.

Cleveland, R., Cleveland, W., McRae, J., Terpenning, I., 1990. STL: a seasonal-trend decomposition procedure based on Loess. J. Offic. Stat.

Congedo, P.M., Malvoni, M., Mele, M., De Giorgi, M.G., 2013. Performance measurements of monocrystalline silicon PV modules in South-eastern Italy. Energy Convers. Manage. 68, 1-10. https://doi.org/10.1016/j.enconman.2012.12.017.

Drif, M., Pérez, P.J., Aguilera, J., Almonacid, G., Gomez, P., de la Casa, J., Aguilar, J.D., 2007. Univer project. A grid connected photovoltaic system of $200 \mathrm{kWp}$ at Jaén University. Overview and performance analysis. Sol. Energy Mater. Sol. Cells 91, 670-683. https://doi.org/10.1016/J.SOLMAT.2006.12.006.

Dubey, et al., 2013. All-India survey of photovoltaic module degradation: 2013. In: National Centre for Photovoltaic Research and Education.

Dubey, S., Sarvaiya, J.N., Seshadri, B., 2013. Temperature dependent photovoltaic (PV) efficiency and its effect on PV production in the world - a review. Energy Procedia 33, 311-321. https://doi.org/10.1016/J.EGYPRO.2013.05.072.

Dubey, R., Chattopadhyay, S., Kuthanazhi, V., John, J., Ansari, F., Rambabu, S., Arora, B. M., Kottantharayil, A., Narasimhan, K.L., Vasi, J., Bora, B., All India survey of photovoltaic module reliability 2014. In: National Centre for Photovoltaic Research and Education.

Elhadj Sidi, C.E.B., Ndiaye, M.L., El Bah, M., Mbodji, A., Ndiaye, A., Ndiaye, P.A., 2016. Performance analysis of the first large-scale (15 MWp) grid-connected photovoltaic plant in Mauritania. Energy Convers. Manage. 119, 411-421. https://doi.org/10. 1016/J.ENCONMAN.2016.04.070.

Golive et al., 2018. All-India survey of photovoltaic module reliability: 2018. In: National Centre for Photovoltaic Research and Education.

Han, H., Dong, X., Li, B., Yan, H., Verlinden, P.J., Liu, J., Huang, J., Liang, Z., Shen, H., 2018. Degradation analysis of crystalline silicon photovoltaic modules exposed over 30 years in hot-humid climate in China. Sol. Energy 170, 510-519. https://doi.org/ 10.1016/j.solener.2018.05.027.

Holt, C.C., 2004. Forecasting seasonals and trends by exponentially weighted moving averages. Int. J. Forecast. 20, 5-10. https://doi.org/10.1016/j.ijforecast.2003.09. 015.

Huang, C., Edesess, M., Bensoussan, A., Tsui, K.L., 2016. Performance analysis of a gridconnected upgraded metallurgical grade silicon photovoltaic system. Energies 9. https://doi.org/10.3390/en9050342.

Huang, C., Wang, L., 2018. Simulation study on the degradation process of photovoltaic modules. Energy Convers. Manage. 165, 236-243. https://doi.org/10.1016/j. enconman.2018.03.056

IEA-PVPS, 2014. Analysis of Long-Term Performance of PV Systems Different Data Resolution for Different Purposes.

IEC61724, 1998. Photovoltaic system performance monitoring-guidelines for measurement, data exchange and analysis.

Ishii, T., Takashima, T., Otani, K., 2011. Long-term performance degradation of various kinds of photovoltaic modules under moderate climatic conditions. Prog. Photovoltaics Res. Appl. 19, 170-179. https://doi.org/10.1002/pip.1005.

Jäger-Waldau, A., 2018. PV Status Report 2018.

JCGM, 2008. Evaluation of measurement data-Guide to the expression of uncertainty in measurement Évaluation des données de mesure-Guide pour l'expression de l'incertitude de mesure.

Jordan, D.C., Kurtz, S.R., 2013. Photovoltaic degradation rates-an analytical review. Prog. Photovoltaics Res. Appl. 21, 12-29. https://doi.org/10.1002/pip.1182.

Kichou, S., Abaslioglu, E., Silvestre, S., Nofuentes, G., Chouder, A., Torres-Ramírez, M., 2016a. Study of degradation and evaluation of model parameters of micromorph silicon photovoltaic modules under outdoor long term exposure in Jaén, Spain. Energy Convers. Manage. 120, 109-119.

Kichou, Sofiane, Silvestre, S., Nofuentes, G., Torres-Ramírez, M., Chouder, A., Guasch, D., 2016b. Characterization of degradation and evaluation of model parameters of amorphous silicon photovoltaic modules under outdoor long term exposure. Energy 96, 231-241. https://doi.org/10.1016/j.energy.2015.12.054.

Kichou, S., Wolf, P., Silvestre, S., Chouder, A., 2018. Analysis of the behaviour of cadmium telluride and crystalline silicon photovoltaic modules deployed outdoor under humid continental climate conditions. Sol. Energy 171, 681-691. https://doi.org/10. 1016/j.solener.2018.07.028.

Kiefer, K., Farnung, B., Müller, B., Reinartz, K., Rauschen, I. and Klünter, C., 2018. Degradation in PV power plants: theory and practice. In: Proceedings of 36th European PV Solar Energy Conference and Exhibition, 9-13 September 2018, Marseille, France.

Kumar, N.M., Dasari, S., Reddy, J.B., 2018. Availability factor of a PV power plant: evaluation based on generation and inverter running periods. Energy Procedia 147, 71-77. https://doi.org/10.1016/j.egypro.2018.07.035.

Kumar, N.M., Gupta, R.P., Mathew, M., Jayakumar, A., Singh, N.K., 2019a. Performance, energy loss, and degradation prediction of roof-integrated crystalline solar PV system 
installed in Northern India. Case Stud. Therm. Eng. 13, 100409. https://doi.org/10. 1016/J CSITE 2019.100409.

Kumar, N.M., Prabaharan, N., Jerin, A.R.A., 2019b. Impact of performance degradation and capital subsidy on the revenue of rooftop solar PV system. Int. J. Renew. Energy Res. (IJRER) 9 (1), 128-136.

Kumar, N.M., Malvoni, M., 2019. A preliminary study of the degradation of large-scale cSi photovoltaic system under four years of operation in semi-arid climates. Res. Phys. 12, 1395-1397. https://doi.org/10.1016/j.rinp.2019.01.032.

Kumar, N.M., Subathra, M.S.P., 2019. Three years ahead solar irradiance forecasting to quantify degradation influenced energy potentials from thin film (a-Si) photovoltaic system. Res. Phys. 12, 701-703. https://doi.org/10.1016/J.RINP.2018.12.027.

Kurnik, J., Jankovec, M., Brecl, K., Topic, M., 2011. Outdoor testing of PV module temperature and performance under different mounting and operational conditions. Sol. Energy Mater. Sol. Cells 95, 373-376. https://doi.org/10.1016/j.solmat.2010.04. 022 .

Kymakis, E., Kalykakis, S., Papazoglou, T.M., 2009. Performance analysis of a grid connected photovoltaic park on the island of Crete. Energy Convers. Manage. https://doi. org/10.1016/j.enconman.2008.12.009.

Lindig, S., Kaaya, I., Weis, K.-A., Moser, D., Topic, M., 2018. Review of statistical and analytical degradation models for photovoltaic modules and systems as well as related improvements. IEEE J. Photovoltaics 8, 1773-1786. https://doi.org/10.1109/ JPHOTOV.2018.2870532.

Makridakis, S, Wheelwright, S., Hyndman, R., 1998. Forecasting: Methods and Applications, third ed. New York: John Wiley \& Sons. https://doi.org/10.1016/00246301(84)90207-3.

Makrides, G., Zinsser, B., Schubert, M., Georghiou, G.E., 2014. Performance loss rate of twelve photovoltaic technologies under field conditions using statistical techniques. Sol. Energy 103, 28-42. https://doi.org/10.1016/j.solener.2014.02.011.

Malvoni, M., De Giorgi, M.G., Congedo, P.M., 2017a. Study of degradation of a grid connected photovoltaic system. Energy Procedia 644-650. https://doi.org/10.1016/ j.egypro.2017.08.263.

Malvoni, M., Fiore, M.C., Maggiotto, G., Mancarella, L., Quarta, R., Radice, V., Congedo, P.M., De Giorgi, M.G., 2016. Improvements in the predictions for the photovoltaic system performance of the Mediterranean regions. Energy Convers. Manage. 128. https://doi.org/10.1016/j.enconman.2016.09.069.

Malvoni, M., Leggieri, A., Maggiotto, G., Congedo, P.M., De Giorgi, M.G., 2018. Corrigendum to long term performance, losses and efficiency analysis of A $960 \mathrm{Kwp}$ photovoltaic system in the mediterranean climate [energy conversion and management 145 (2017) 169-181]. Energy Convers. Manage. 159, 413. https://doi.org/10 1016/j.enconman.2018.02.019.

Malvoni, M., Leggieri, A., Maggiotto, G., Congedo, P.M., De Giorgi, M.G., 2017b. Long term performance, losses and efficiency analysis of a $960 \mathrm{kWP}$ photovoltaic system in the Mediterranean climate. Energy Convers. Manage. 145, 169-181. https://doi.org/ 10.1016/j.enconman.2017.04.075.

Masuko, K., Shigematsu, M., Hashiguchi, T., Fujishima, D., Kai, M., Yoshimura, N., Yamaguchi, T., Ichihashi, Y., Mishima, T., Matsubara, N., Yamanishi, T., Takahama, T., Taguchi, M., Maruyama, E., Okamoto, S., 2014. Achievement of more than $25 \%$ conversion efficiency with crystalline silicon heterojunction solar cell. IEEE J. Photovoltaics 4, 1433-1435. https://doi.org/10.1109/JPHOTOV.2014.2352151.

Mensah, L.D., Yamoah, J.O., Adaramola, M.S., 2019. Performance evaluation of a utilityscale grid-tied solar photovoltaic (PV) installation in Ghana. Energy Sustain. Dev. 48, 82-87. https://doi.org/10.1016/j.esd.2018.11.003.

Ministry of New and Renewable Energy, 2017. http://mnre.gov.in/related-links/jnnsm/ introduction-2/.

Munoz, M.A., Vela, N., Chenlo, F., Alonso-García, M.C., 2011. Early degradation of silicon PV modules and guaranty conditions. Solar Energy 85, 2264-2274.

Ndiaye, A., Charki, A., Kobi, A., Kébé, C.M.F., Ndiaye, P.A., Sambou, V., 2013. Degradations of silicon photovoltaic modules: a literature review. Sol. Energy 96, 140-151. https://doi.org/10.1016/j.solener.2013.07.005.

Ogbomo, O.O., Amalu, E.H., Ekere, N.N., Olagbegi, P.O., 2018. Effect of operating temperature on degradation of solder joints in crystalline silicon photovoltaic modules for improved reliability in hot climates. Sol. Energy 170, 682-693. https://doi.org/ 10.1016/j.solener.2018.06.007.

Ozden, T., Akinoglu, B.G., Turan, R., 2017. Long term outdoor performances of three different on-grid PV arrays in central Anatolia - an extended analysis. Renew. Energy. https://doi.org/10.1016/j.renene.2016.08.045.

Padmavathi, K., Daniel, S.A., 2013. Performance analysis of a 3MWp grid connected solar photovoltaic power plant in India. Energy Sustain. Dev. 17, 615-625. https://doi. org $/ 10.1016 /$ j.esd.2013.09.002.

Phinikarides, A., Kindyni, N., Makrides, G., Georghiou, G.E., 2014a. Review of photovoltaic degradation rate methodologies. Renew. Sustain. Energy Rev. 40, 143-152. https://doi.org/10.1016/j.rser.2014.07.155.

Phinikarides, A., Makrides, G., Georghiou, G.E., 2013. Comparison of analysis methods for the calculation of degradation rates of different photovoltaic technologies. In: 28th EU-PVSEC. https://doi.org/10.4229/28thEUPVSEC2013-5BV.4.39.
Phinikarides, A., Makrides, G., Kindyni, N., Georghiou, G.E., 2014b. Comparison of trend extraction methods for calculating performance loss rates of different photovoltaic technologies. In: 2014 IEEE 40th Photovoltaic Specialist Conference, PVSC 2014. pp. 3211-3215. https://doi.org/10.1109/PVSC.2014.6925619.

Phinikarides, A., Makrides, G., Zinsser, B., Schubert, M., Georghiou, G.E., 2015. Analysis of photovoltaic system performance time series: seasonality and performance loss. Renew. Energy 77, 51-63. https://doi.org/10.1016/j.renene.2014.11.091.

Pundir, K.S.S., Varshney, N., Singh, G.K., 2016. Comparative study of performance of grid connected solar photovoltaic power system in campus. In: Proceedings of International Conference on Innovative Trends in Science Engineering and Management New Delhi.

PV Degradation, University of Cyprus Photovoltaic Technology Park, in Nicosia, Cyprus. http://www.foss.ucy.ac.cy/projects/pvdegradation/index.html.

Quansah, D.A., Adaramola, M.S., 2019. Assessment of early degradation and performance loss in five co-located solar photovoltaic module technologies installed in Ghana using performance ratio time-series regression. Renew. Energy 131, 900-910.

Rajput, P., Malvoni, M., Kumar, N.M., Sastry, O.S., Tiwari, G.N., 2019. Risk priority number for understanding the severity of photovoltaic failure modes and their impacts on performance degradation. Case Stud. Therm. Eng. 16, 100563.

Rajput, P., Sastry, O.S., Tiwari, G.N., 2017. Effect of irradiance, temperature exposure and an Arrhenius approach to estimating weathering acceleration factor of Glass, EVA, and Tedlar in a composite climate of India. Sol. Energy 144, 267-277. https://doi. org/10.1016/j.solener.2017.01.027.

Rajput, P., Malvoni, M., Manoj Kumar, N., Sastry, O.S., Jayakumar, A., 2020. Operational performance and degradation influenced life cycle environmental-economic metrics of mc-Si, a-Si and HIT photovoltaic arrays in hot semi-arid climates. Sustainability 12 , 1075.

Rubel, F., Kottek, Markus, 2010. Observed and projected climate shifts 1901-2100 depicted by world maps of the Koppen-Geiger climate classification World Map of Köppen - geiger climate classification. Meteorol. Z. https://doi.org/10.1127/09412948/2010/0430.

Sharma, V., Chandel, S.S., 2013a. Performance and degradation analysis for long term reliability of solar photovoltaic systems: a review. Renew. Sustain. Energy Rev. 27, 753-767. https://doi.org/10.1016/j.rser.2013.07.046.

Sharma, V., Chandel, S.S., 2013b. Performance analysis of a 190kWp grid interactive solar photovoltaic power plant in India. Energy 55, 476-485. https://doi.org/10. 1016/j.energy.2013.03.075.

Shiva Kumar, B., Sudhakar, K., 2015. Performance evaluation of 10 MW grid connected solar photovoltaic power plant in India. Energy Rep. 1, 184-192. https://doi.org/10. 1016/j.egyr.2015.10.001.

Shukla, A.K., Sudhakar, K., Baredar, P., 2016. Simulation and performance analysis of $110 \mathrm{kWp}$ grid-connected photovoltaic system for residential building in India: a comparative analysis of various PV technology. Energy Rep. 2, 82-88. https://doi. org/10.1016/j.egyr.2016.04.001.

Silvestre, S., Kichou, S., Guglielminotti, L., Nofuentes, G., Alonso-Abella, M., 2016. Degradation analysis of thin film photovoltaic modules under outdoor long term exposure in Spanish continental climate conditions. Sol. Energy 139, 599-607. https://doi.org/10.1016/J.SOLENER.2016.10.030.

Silvestre, S., Tahri, A., Tahri, F., Benlebna, S., Chouder, A., 2018. Evaluation of the performance and degradation of crystalline silicon-based photovoltaic modules in the Saharan environment. Energy 152, 57-63. https://doi.org/10.1016/j.energy.2018. 03.135 .

Sundaram, S., Babu, J.S.C., 2015. Performance evaluation and validation of 5 MW grid connected solar photovoltaic plant in South India. Energy Convers. Manage. https:// doi.org/10.1016/j.enconman.2015.04.069.

SunPower, 2013. SunPower ${ }^{\circledast}$ Module Degradation Rate. Available online: https:// energyhub.org/wp-content/uploads/2018/05/SunPower-Module-Degredation-PDF pdf.

Tabatabaei, S.A., Formolo, D., Treur, J., 2017. Analysis of performance degradation of domestic monocrystalline photovoltaic systems for a real-world case, in: Energy Procedia. Behavioural Informatics Group, Computer Science Department, VU University Amsterdam, Netherlands, pp. 121-129. https://doi.org/10.1016/j.egypro. 2017.09.025.

Weaver, Brian P., Meeker, William Q., Escobar, Luis A., Wendelberger, Joanne, 2013. Methods for planning repeated measures degradation studies. Technometrics 55 (2), 122-134. https://doi.org/10.1080/00401706.2012.715838.

Winters, P.R., 1960. Forecasting sales by exponentially weighted moving averages. Manage. Sci. 6, 324-342. https://doi.org/10.1287/mnsc.6.3.324.

Wittkopf, S., Valliappan, S., Liu, L., Ang, K.S., Cheng, S.C.J., 2012. Analytical performance monitoring of a $142.5 \mathrm{kWp}$ grid-connected rooftop BIPV system in Singapore. Renew. Energy 47, 9-20. https://doi.org/10.1016/J.RENENE.2012.03.034.

Woyte, A., Richter, M., Reich, N., Green, M., Mau, S., Hassan, G.G., Beyer, H.G., 2014. Analytical monitoring of grid-connected photovoltaic systems good practices for monitoring and performance analysis. IEA-Photovolt. Power Syst. Program. 1-90. https://doi.org/10.13140/2.1.1133.6481. 